\title{
Hunter-Gatherer Foraging: A Linear Programming Approach
}

\author{
GARY E. BELOVSKY \\ School of Natural Resources and Department of Biological Sciences, The University of \\ Michigan, Ann Arbor, Michigan 48109-1115
}

Received March 17, 1986

\begin{abstract}
A linear program model is developed to examine how much effort huntergatherers should devote to hunting vs gathering. This foraging model contains a foraging time, a digestive capacity, and a nutritional constraint which determine the optimal solution to a given human foraging goal: nutritional maximization, foraging time minimization, risk aversion, or food storage maximization. The model is compared with the most commonly used foraging models in anthropology and is shown to be more appropriate for hunter-gatherers. Using data on present day hunter-gatherers, the model's solution is shown to indicate quantitatively that these people tend to either maximize their energy or protein intake rather than minimize their time spent providing for their energy and protein needs. The model also predicts diet proportions, absolute food intake, time spent foraging, and sexual division of labor. A general version of the model is developed where the hunting and gathering cropping rates are made functions of environmental primary production. The solutions to this model agree with world patterns of hunter-gatherer diets, foraging time, and sexual division of labor. Modifications of the model to investigate risk-averse foraging and food storage are also presented, and the model is applied to determine when agriculture/pastoralism might be adopted and how hunter-gatherer body size might be selected. Although the model appears closely to predict observed hunter-gatherer foraging, the model's sensitivity and the quality of the data available make its uncritical acceptance unwarranted at this time. (c) 1987 Academic Press, Inc.
\end{abstract}

\section{INTRODUCTION}

Smith (1979) reviewed the question of whether or not human foraging efficiency has increased through human evolutionary history. He argues that early hominid inclusive fitness (survival and reproduction) should have increased with greater acquisition of net energy while foraging. This argument would be valid whether man encountered conditions of absolute food limitation or needed to spend more time on activities other than foraging. In the first case, absolute food intake is assumed to control individual reproductive success and survival. In the latter case, quicker 
fulfillment of nutritional needs leaves more time for additional activities that might be more important to survival and reproducton. These two alternative strategies for increasing an individual's fitness have been called energy maximization and time minimization in foraging ecology (Schoener 1971; Pyke et al. 1977; Pyke 1984; Stephens and Krebs 1986; Krebs et al. 1983; Hixon 1982) and under some, but not all, conditions form endpoints of a continuum (see Winterhalder 1983).

More recently, Winterhalder and Smith (1981) edited a volume dealing with the application of optimal foraging theory from ecology (Schoener 1971; Pyke et al., 1977; Krebs et al., 1983; Stephens and Krebs 1986; Pyke 1984) to the behavior of human hunter-gatherers. Smith (1983), Martin (1983), and Durham (1981) have reviewed the successes/failures of applying foraging theory to humans. These analyses and a large number of other anthropological studies (see below) indicate that humans appear, at least in some cases, to follow some of the predictions from foraging theory. Similar arguments have been employed in archaeological studies (see Earle and Christenson 1980).

Foraging theory for humans (Smith 1983) can be used to address three questions: what should be eaten, where food should be sought, and how large a group is needed to exploit the food. The first two questions have been the ones most frequently addressed using foraging theory, and will be the focus of this paper. A number of anthropological studies have employed optimal foraging models to examine hunter-gatherer diet choice (e.g., Hawkes et al., 1982, 1985; Hill et al. 1984, 1985; O'Connell and Hawkes 1981; Hawkes and O'Connell 1981; Winterhalder 1980, 1981a; Kaplan and Hill 1985a, 1985b; Hurtado et al., 1985; Keene 1981; Yesner 1981; Hames and Vickers 1982).

Applications of foraging theory to anthropology and archaeology have largely been qualitative (as defined by Krebs et al., 1983), meaning that predictions of the theory are compared to observed behavior via ranking or "yes vs no" approaches. Krebs et al. (1983) argue that this methodology provides an initial indication that the theory may have applicability, but it does not constitute adequate rigor to test the utility of these models.

To achieve the needed power to demonstrate the utility of foraging theory, quantitative predictions of the theory must be compared with observed behaviors (e.g., mass of each food consumed, minutes spent foraging, etc.). This also requires assessing whether the forager tends to choose a strategy which is more consistent with energy/nutrient maximization, foraging time minimization, or possibly some other strategy such as minimizing the risk of going hungry. Indeed, Martin (1983) criticizes anthropological studies of foraging theory because of their qualitative, 
rather than quantitative nature. This, however, is also a problem with foraging studies for other organisms (Krebs et al., 1983).

Recently, a debate has emerged concerning what type of foraging model is most useful for defining hunter-gatherer diet choices and what are the nutritional components of foods that people might seek (Hawkes and O'Connell 1985; Sih and Milton 1985). Even more extreme have been claims that optimality approaches might not really work (Martin 1983; Durham 1981) or are simply jargon (Dwyer 1982, 1983, 1985; Dwyer and Minnegal 1985; Martin 1983). To progress beyond this debate, quantitative tests of diet choice models must be developed for hunter-gatherers.

Whether hunter-gatherers tend to maximize their nutritional (e.g., energy, protein, etc.) intake, minimize their foraging time, or deviate from these two extreme strategies must be determined. Deviations might arise because the forager attempts to minimize the "risk" of failing to achieve nutritional needs given variation in the success of finding food (risk aversion: sensu Caraco 1980a, 1980b, 1981), or the need to devote time to other activities (see Winterhalder 1983). These possibilities can be addressed by quantitatively solving foraging models and comparing the results with observed behaviors. An answer to whether or not huntergatherers tend to forage to maximize their nutritional intake or minimize their foraging time will also help to discern whether absolute food intake or time for other activities is more important to their lifeways (Hawkes et al. 1985).

The optimal foraging model developed here for hunter-gatherers is very different from that commonly employed in anthropological studies. The model employs the technique of linear programming. Linear programming has been employed in archaeological studies of hunter-gatherers to predict the relative value of different foodstuffs (Keene 1981, 1982; Reidhead 1980); however, these models were qualitative predictors, not quantitative models (Keene 1982:167).

The model developed here is quantitative and incorporates a different form. of food search that may be more appropriate for humans than the form commonly used in anthropological foraging models. This type of food search enables us to examine the potential for the division of labor between the sexes. The model also includes a digestive limit on food consumption per unit of time which enables an examination of when food storage might be important to hunter-gatherers in a varying environment.

The optimal foraging model is solved for Kalahari San and Peruvian Aché (Lee and DeVore 1976; Lee 1968, 1979; Tanaka 1976; Hawkes 1982, 1985). The solutions indicate that these hunter-gatherers tend to allocate time for hunting and gathering in a fashion that maximizes their daily 
energy and/or protein intake rather than minimizing foraging time. Finally, with the model and a function relating environmental primary production to cropping rates for hunting and gathering, the observed diet variation for other groups (Lee 1968; Hayden 1981) is shown possibly to arise from a feeding strategy which tends to maximize energy or protein intake.

The model is also used to hypothesize how environmental changes might induce a transition from a hunting-gathering to an agricultural society. This is used to illustrate the potential value of a foraging limitation approach for answering archaeological questions about early hominid adaptations (Freeman 1981; Mann 1981; Binford 1980, 1985; Webster 1981; Webster and Webster 1984), by extrapolating from a model based on current observations of hunter-gatherers.

This is not to claim that modern hunter-gatherers choose the same diets as early hominids, because modern hunter-gatherers live in different environments, which include the provision of mission food, government policies toward hunter-gatherers, and market economies. Rather modern hunter-gatherers serve to "test" whether humans are capable of making the optimal foraging decisions that might satisfy different goals, and what these goals might be. With knowledge of these capabilities and goals, we can make some educated "guesses" about early hominid behavior in different environments.

Before proceeding with the model and its predictions, several words of caution are appropriate. First, foraging ecology models have been built on the premise that foraging decisions impact individual fitness (i.e., limit survival and reproduction). This assumption, although not unreasonable, has seldom been demonstrated except for a few animals [e.g., molluscs (Garton 1984; Garton et al., 1984); Columbian ground squirrels (M. Ritchie, personal communication); and garter snakes (Arnold 1981)]. For humans this assumption is even less substantiated except for work by Kaplan and Hill (1985a, 1985b, 1986) with the Aché (see Minnegal and Dwyer 1986, for a rebuttal) and various models of hunter-gatherer nutrition (e.g., Leslie 1984; Bentley 1985). Without further data which will be very difficult to obtain, this assumption cannot be tested; however, foraging models based upon this assumption can be tested and if not refuted, the premise would appear plausible.

Second, none of the data in the anthropological literature of which I am aware is complete enough to construct a foraging model with the degree of detail found in many ecological studies. Some studies are very complete for some of the needed parameters, but provide only qualitative data for other necessary parameters. Some very complete studies (e.g., Winterhalder 1977) are complicated by the exigencies of market econ- 
omies. Therefore, any model developed will be lacking in the desired quality of the needed parameters.

Finally, even with the more complete data available in many ecological studies, the validity of foraging models is still being debated among ecologists (Pyke 1984; Stephens and Krebs 1986). In particular, the models' simple reductionist approaches are questioned. Simplicity and reductionism are good starting points for any quantitative science (Smith 1983) and should not be shunned outright, rather quantitative predictiveness should be their test. Therefore, the successes of the models presented in this paper should be tantalizing. Because of the problems with the existing data, however, the models remain heuristic tools that suggest how future studies might improve our confidence in the models and how more quantitative data and theories might be developed in anthropology (Borgerhoff Mulder and Caro 1985). In my opinion, the available data simply are not strong enough to establish the validity of the models for humans at this time.

\section{MODEL CONSTRUCTION AND PARAMETERS}

In developing any quantitative model of foraging, a precise mathematical expression which is based upon specific forager and environmental characteristics must be constructed. Once a model is developed, parameter values must be obtained, the model must be solved, its predictions must be compared with observed behavior, and finally the sensitivity of the model to parameter changes must be addressed.

\section{Model Construction}

Optimal foraging models in ecology (Schoener 1971; Pyke et al., 1977; Krebs et al., 1983; Pyke 1984; Stephens and Krebs 1986) address a number of different circumstances. The simplest models used to solve foraging questions are deterministic (Schoener 1971; Werner and Hall 1974; Charnov 1976; Belovsky 1978, 1984a, 1984b, 1984c; Krebs et al., 1977). This means that the model parameters are considered to be constants. These models have been developed using two simple premises. First, if survival and reproduction are limited by food intake, then a forager should maximize its nutritional intake. Second, if survival and reproduction are limited by the time a forager has for activities other than feeding, then the forager should minimize the foraging time needed to satisfy minimum food intake. These two premises are straightforward; however, the construction of models to find solutions to these problems varies with different environmental conditions and constraints on the for- 
ager (McNair 1979; Belovsky 1984a, 1984b, 1984c; Pulliam 1975; Westoby 1974; Winterhalder 1983).

Another set of more recent models is not deterministic but allows parameter values to vary. These models have dealt with risk aversion (Caraco 1980a, 1980b, 1981) and stochastic events (Green 1980; Oaten 1977). Risk averse models incorporate the additional idea that food encounter rates vary around an expected value, and they ask what is the diet which minimizes the chances of the forager failing to achieve its nutritional requirements. Stochastic models either maximize nutritional intake or minimize feeding time given the inability of the forager to know the foraging environment with certainty.

To model hunter-gatherer foraging, I chose to employ a deterministic model. This choice was based on expedience and necessity, the former because deterministic models are simpler, the latter because the available data do not warrant a more complex model. Given limited data, the predictions of a simple deterministic model can be tested more easily and a determination can be made as to whether a more complex model is warranted. What type of deterministic model should be used? To answer this question, the environmental and forager characteristics must be assessed to ensure that the assumptions used in developing the model are appropriate (i.e., there is no single appropriate model for all organisms or environments).

Contingency model. Most foraging studies in anthropology have used the contingency model of foraging (Schoener 1971; Pulliam 1974; Charnov 1976; Werner and Hall 1974; Krebs et al., 1977). This model is very attractive since it requires simply an ability to rank foods in terms of their nutritional value per unit of handling time, predicts on this basis whether a food will be consumed and if a food is predicted to be consumed, it is eaten in proportion to its abundance in the environment. An additional nicety is that the nutritional maximizing and time minimizing diets have the same diet proportions.

This model is based upon only two possible limits to the forager's diet selection: nutritional needs, if it is a time minimizer, and time available for feeding over a longer period (e.g., day), if it is a nutrition maximizer. In addition, the model is built on the assumption that the forager can employ simultaneous search, i.e., look for and harvest all foods at the same time. Simultaneous search is appropriate if the foods are randomly or uniformly distributed in the environment and they can be searched for and harvested using similar behavioral modes. If different search behaviors are needed, if other food distributions occur in the environment (e.g., clumped) or if other constraints are operative, then the contingency model will rapidly lead to fallacious predictions (Westoby 1974; Pulliam 1975; Belovsky 1978; McNair 1979). There are some good reasons to ex- 
pect hunter-gatherers' foraging to violate the assumptions of the contingency model.

First, the simultaneous search assumption of the contingency model is violated. Humans are omnivorous; therefore, the wide range of foods consumed will not likely be distributed in the same locations or require the same search and harvesting behaviors. Discussions of hunting-gathering (Lee and DeVore 1968) suggest that the decision by an individual to perform one type of foraging (e.g., hunting) may preclude the individual's simultaneous adoption of another type of food acquisition (e.g., gathering) during short time periods (e.g., day). The necessity to choose between hunting and gathering might arise because hunted and gathered foods occur in separate environmental patches and/or require different foraging modes (e.g., tools). Certainly, gathered foods do not always occur where game is dwelling. More important, hunting requires very different activities than gathering (such as stalking, ambushing, etc.) and gathering may frighten game out of the area. Dwyer (1985:68-69) argues that this constraint to search is crucial to people in Papua New Guinea. This condition, however, has been largely ignored in the development of foraging models for hunter-gatherers.

A second consideration is digestive capacity. This also is commonly ignored, and may be of importance to hunter-gatherers. While many organisms may have their diet choice constrained by their ability to process different quantities of food in their digestive tract (Taghon 1981; Belovsky 1984a), this constraint may take on additional meaning for humans since they are omnivorous. Very different types of foods utilize digestive capacity very differently, which may change their apparent nutritional value (e.g., a food high in energy also might take up disproportionately more digestive capacity, in essence "diluting" its value). Also, since people can store foods, their diet choice may not be constrained by the current time frame's (e.g., daily) digestive capacity but by the digestive constraint for the current period plus some future period when stored foods will be utilized. This requires consideration of the need for food storage in varying environments.

Finally, other nutritional constraints than energy and protein may be important to hunter-gatherers. Water in the arid environment of the G/wi San (Silberbauer 1981a) is an example. These constraints can dramatically change a forager's diet choice (Belovsky 1978, 1984b). Mann (1981) lists and discusses a number of other potential nutritional constraints for hunter-gatherers.

Obviously, with all of these different and modified feeding constraints, the contingency model, the model most frequently used in anthropological studies, may be inappropriate. The feeding time constraint described above for hunter-gatherers is incorporated by reducing the time avail- 
able for feeding on other foods by each time unit spent feeding on one food. This is a linear constraint called nonsimultaneous search, since all foods cannot be searched for simultaneously. In the absence of information to the contrary, all the other constraints (digestive, nutrient, etc.) can be formulated as linear functions (Belovsky 1984a). Given a series of linear constraints, a method called linear programming can be used to solve for various optimal solutions to different goals.

Linear program model. Linear programming may provide a far more realistic method for modelling human foraging than the contingency model. Indeed, Sih and Milton (1985) have debated the value of the contingency model for hunter-gatherers with Hawkes and O'Connell (1985). Keene $(1981,1982)$ and Reidhead (1980) have used linear program models of hunter-gatherer foraging to address archaeological questions. These models, however, were qualitative (rank data) and assumed that the people only sought to satisfy their nutritional needs in the least time (time minimizer). Durham (1981), Martin (1983), and Mann (1981) have argued for more realistic and quantitative linear program models for human foraging; on the other hand, it is important to construct a model that is still simple enough to permit some general applicability.

In building a linear program model for hunter-gatherer foraging, only two food categories will be used: hunted and gathered foods. This is done for simplicity and because the data from most anthropological studies either do not give adequate cropping times to distinguish between component food species or do not describe how the component species are distributed in the environment (e.g., patchiness and abundance). Nevertheless, these two food categories capture the essence of hunter-gatherer foraging because of the anthropological debate (Lee and DeVore 1968; Hayden 1981) over how important these two food sources are to people.

In constructing a linear program model, foraging constraints are written as $C \geqslant k_{1} H+k_{2} G$ (e.g., nutritional requirements), or $C \leqslant k_{1} H+$ $k_{2} G$ (e.g., foraging time and digestive capacity), where $C$ is a limitation (constraint) on foraging; $H$ and $G$ are the quantities of food in the diet acquired by hunting and/or gathering, respectively; $k_{1}$ is a quantity converting $H$ into the constraint value and $k_{2}$ converts $G$ into the constraint value.

Two extreme foraging goals can be considered potentially important for people: (1) nutrient intake maximization or (2) feeding time minimization. Modifications of either of the goals arising from the minimization of the risk of going hungry or the need for time spent in other activities can also be addressed. Either extreme goal can be solved for using a linear program model. The solution for each one of the goals will occur at the intersection of two constraint equations or one constraint equation with an axis. This simple solution to the model arises because only two quan- 
tities, foods from hunting and gathering, are considered. A more detailed description of a linear program model for feeding is presented by $\mathrm{Be}-$ lovsky (1984a). Finally, it is possible that one or both of the foraging goals cannot be attained by the forager given its constraints; therefore, a solution is not guaranteed.

To solve a linear program model for hunter-gatherers, several questions must be addressed that are particular to humans: (1) the foraging unit (individual, family, group, etc.), (2) sexual division of labor, and (3) the importance of food storage.

The foraging unit employed in diet selection studies for most organisms is a single individual; however, for humans it may be more appropriate to consider diet selection for more than a single individual, such as the family or group, because of food sharing. Whether food sharing occurs only among nuclear family members, a greater range of kin or a larger group, not including kin, depends upon cultures and time of year, (e.g., Kaplan et al. 1984; Kaplan and Hill 1985a, 1985b; Cashdan 1984; Smith 1985; Silberbauer 1981a, 1981b, 1982; Lee 1979, 1982; Wiessner 1982; Blackburn 1982; Gould 1981; Hayden 1981). Food sharing may be a means of reducing the risk of going hungry through one individual's or family's failure to find food (Gould 1981; Wiessner 1982; Kaplan et al. 1984; Kaplan and Hill 1985a, 1985b; Smith 1985). To address whether individuals do better by sharing food requires knowledge of the variances in daily food acquisition success rates (see Kaplan and Hill 1985a, 1985b). In most studics this data is unavailable; therefore, the causes of food sharing will not be addressed in the model presented here.

The model, however, can be used to determine how diet choice might change between an individual provisioning him or herself and the family/ group sharing foods. The diets chosen under family vs. group sharing cannot be distinguished with the available data since most studies only present data on the average foraging success, number of dependents and diets within a group. This makes the group simply the number of families times the average family data.

The sexual division of labor in food acquisition for hunter-gatherers can be investigated using the model. This is a subject of concern because of cultural differences in food acquisition by men vs women (Lee 1982; Hayden 1981). If we solve for the optimal family or group diet, we can then determine how much of the food acquisition would be attributed to men vs women and if this foraging allocation is observed or is even feasible. This can be done by assuming that men can hunt, gather, or prepare foods, while women can only gather or prepare foods, because of the obligations of child care (Brown 1970; Hayden 1981; Hurtado et al. 1985; Hill et al. 1985; Minge-Klevana 1980).

Food storage can be included in the model by varying the constraints 
in response to the need to acquire additional food and store it for lean times (Gould 1981; Hayden 1981; Binford 1980). It is difficult to model food storage needs for particular people, because none of the anthropological studies provide adequate measures of changes in food availability over the year, except for Hill et al. (1984) with the Aché and Dwyer (1983) with the Etolo. The model, however, can be used to examine the conditions which would lead to hunter-gatherers storing food rather than using accumulated body fat. These predictions can be compared to the general environmental conditions under which hunter-gatherers do store foods.

\section{Model Parameters}

An individual's foraging constraint parameters for the linear program model are developed below, using Richard Lee's (1968, 1979; Lee and DeVore, 1976) data on the !Kung San in winter, as an example. The constraints for the !Kung need only be considered over a daily time period, since Lee (1979) claims that the !Kung do not store food. Later, data on !Kung at other times of the year, other San and the Aché are used to construct linear program models with different constraints.

Daily feeding time can be a potential constraint to people if the time they can be exposed to the environment is limited because of cold, heat, water stress, etc. If a strong correlation is found between when people are active and thermal conditions, and if pcople are shown to be physiologically incapable of foraging at certain times due to an inability to maintain thermal equilibrium, we might conclude that foraging time is constrained by the physical environment. Because of human adaptability to the thermal environment through shelter and clothing, this analysis must use the technology employed by the people and cannot ask what would be the best technology. Nonetheless, this physical explanation, if confirmed, is the most parsimonious and this common pattern with other animals must be acknowledged.

Lee (1979) and Silberbauer (1981a, 1981b) indicate that at different times of the year the San appear to restrict activity because of excessive heat gain or loss, wet weather or loss of water through sweating. This has been documented in several physiological studies of San (Wyndham et al. 1964; Wyndham, 1956) and used in an analysis of !Kung load carrying (Blurton Jones and Sibley 1978). During the period in which Lee intensively measured !Kung diets and foraging activity (winter: July-August), their foraging appears to be limited by heat loss since the nights, evenings and mornings were cold and the !Kung would huddle together near fires. During this period, Lee (1979) estimates that the average !Kung adult spends $363 \mathrm{~min} / \mathrm{day}$ working in feeding related activities (foraging, tool 
construction or repair, and food preparation). Only $27 \mathrm{~min} /$ day are spent in other forms of work.

Using data on human thermal physiology (Table 1), air temperatures reported by Lee (1979), and solar radiation and wind speeds reported for the Kenyan savannah during winter months (Finch 1972a, 1972b), a simple thermal model (Porter and Gates 1969; Gates 1980) can be solved for the lightly clothed San, as reported by Lee (1979):

$$
\Delta H=R+M \pm C-E,
$$

where $\Delta H$ is heat flux $\left(\mathrm{W} \mathrm{m}^{-2}\right), R$ is net radiation absorbed $\left(\mathrm{W} \mathrm{m}^{-2}\right), M$

TABLE 1

Thermal Physiology and Environmental Data Used to Compute the Heat BUDGET OF A SAN

San:

Solar absorptivity

Emmissivity

Solar profile

Surface area

Surface temperature $\left({ }^{\circ} \mathrm{C}\right)$

Respiratory evaporation $\left(\mathrm{W} \mathrm{m}^{-2}\right)$

Body weight $(\mathrm{kg})$

Height $(\mathrm{cm})$

Convection coefficient $\left(\mathrm{W} \mathrm{m} \cdot 2 /{ }^{\circ} \mathrm{C}\right)$

Metabolism at rest

Metabolism at work or increased heat production

Proportion of area exposed to transfer:

Environment:

$\begin{array}{ll}\text { Active } & 1.0 \\ \text { Resting } & 0.5\end{array}$

Air temperature $\left({ }^{\circ} \mathrm{C}\right)$ :

0.82

0.98

0.23

(solar angle $45^{\circ}$ )

$1.35 \mathrm{~m}$

$0.31 t_{\mathrm{e}}+21.4^{a}$

11.3

43.5

152

$8.5 \mathrm{v} .5$

$35.10 \mathrm{~W} \mathrm{~m}^{-2}$

$60 \mathrm{~W} \mathrm{~m}^{-2}$

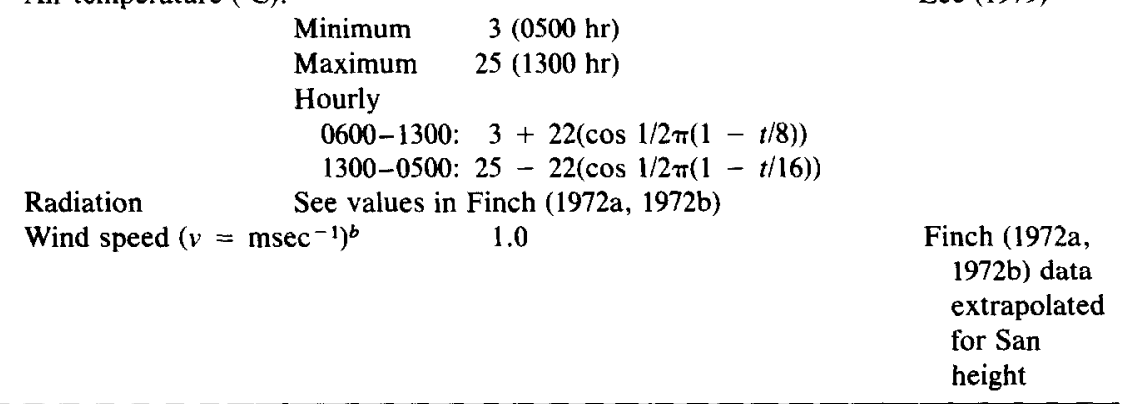

Montieth (1973)

Montieth (1973)

Monticth (1973)

Campbell (1977)

Lee (1964)

Montieth (1973)

Lee (1979)

Lee (1979)

Montieth (1973)

Montieth (1973)

Montieth (1973)

${ }^{a} t_{\mathrm{e}}=$ environmental black body equivalent temperature, Montieth (1973).

$b v=$ wind velocity $\left(\mathrm{msec}^{-1}\right)$. 
is metabolism ( $\left.\mathrm{W} \mathrm{m}^{-2}\right), C$ is convection $\left(\mathrm{W} \mathrm{m}^{-2}\right)$, and $E$ is evaporation $\left(\mathrm{W} \mathrm{m}^{-2}\right) . \Delta H$ is solved for each hour of the day for three types of activity: working in the sun, and sitting or lounging in the sun or in the shade.

The calculations for $\Delta H$ at different times of the day (Fig. 1) indicate that sitting or lounging San require an additional heat source (e.g., fire) at all times during July-August except from 0900 to 1700; working San can do without an additional heat source only from 1000 to 1600 . These differences emerge because sitting or lounging individuals should have less body surface area exposed to the elements than working individuals.

The available periods for work result in a heat gain for San that is well within their ability to dissipate by sweating. The analysis of $\Delta H$ values indicates that San have seven hours on average for work (active in the sun), 0930-1630 ( $\Delta H=0$ with or without sweating), which provides 393 $\mathrm{min} /$ day for foraging $(420 \mathrm{~min}$ for activity less the observed $27 \mathrm{~min}$ for
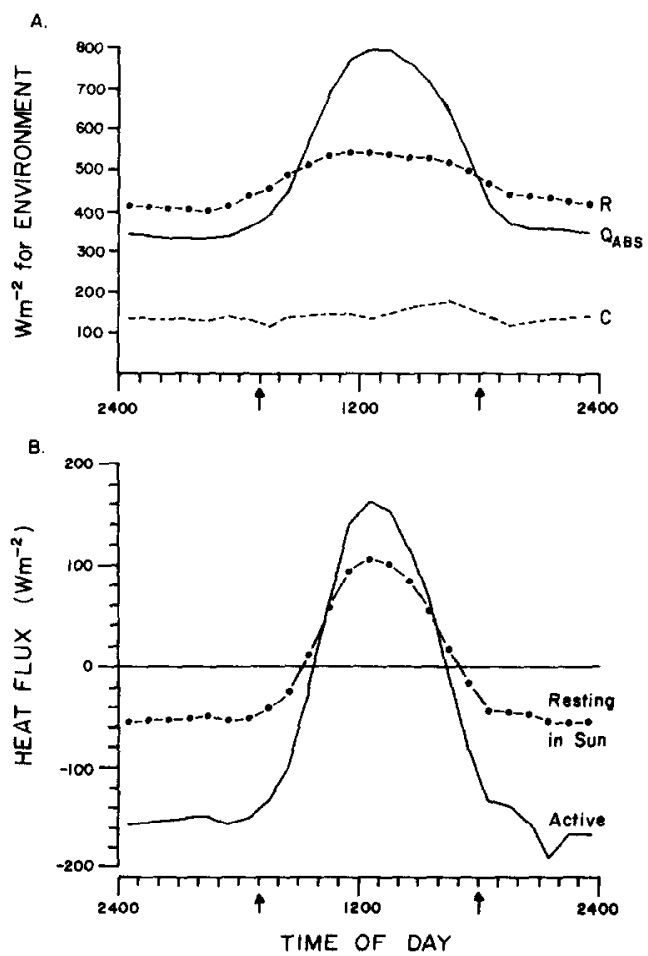

Fig. 1. (A) Thermal parameters for the Kalahari San for each hour from July to August, where $Q_{\mathrm{ABS}}$ is radiation absorbed by a San, $R$ is the radiation reradiated by $S a n$, and $C$ is the convective losses. (B) A Kalahari San's heat flux for each hour of a day in July to August. Arrows in both graphs indicate sunrise and sunset. 
nonforaging work). This value is close to the $363 \mathrm{~min} /$ day observed by Lee (1979), but he does not provide data on when this activity occurs during the day for additional comparison.

The predicted amount of work requires approximately 2 liters of water/ day to replace evaporated sweat, a quantity of water easily provided by the daily diet (Lee 1979), implying no need for considering a water constraint on dict choice for the !Kung. Furthermore, the activity time is less than the daylight period, indicating that light is not limiting the time for work.

Lee (1979) observed that individual San varied the amount of work they performed in a day; this might occur for several reasons. First, days are not average, so that thermal conditions on one day might permit more or less work. Second, an individual might go into thermal or water disequilibrium for a day or two and use the following period for recovery. Nevertheless, an equilibrium must be maintained over some extended time period.

A more detailed optimization model of thermal stress and activity time (Belovsky 1981, 1984c) is not attempted here since the available thermal data are not adequate. However, more complete data would permit us to address the heat budget problems by balancing periods of heat loss against gain, as long as body temperature did not vary outside of lethal limits (Belovsky 1981, 1984c).

The time-motion studies carried out by Lee $(1968,1979)$ on working !Kung (July-August) can be used to determinc their cropping rates for hunted versus gathered foods. Meat requires $0.2 \mathrm{~min} / \mathrm{g}$ in hunting effort $[1 /(206,000 \mathrm{~g} \times 0.9 \mathrm{~g}$ fresh $/ \mathrm{g}$ cooked $) /(78 \mathrm{man}$-days $\times 8 \mathrm{hr} /$ man-day $\times 60$ $\mathrm{min} / \mathrm{hr}$ )]. To cook the meat $0.05 \mathrm{~min} / \mathrm{g}$ is required ( $24 \mathrm{~min} / \mathrm{day})$. The construction and repair of hunting tools requires $0.08 \mathrm{~min} / \mathrm{g}(37.32 \mathrm{~min} /$ day $)$. This leads to a total cropping rate of $0.34 \mathrm{~min} / \mathrm{g}$ of cooked meat.

Mongongo nuts, the main gathered food, require $0.05 \mathrm{~min} / \mathrm{g}$ for collection $[1 /(25$ nuts $/ \mathrm{min} \times 5 \mathrm{~g} /$ nut $\times 0.15 \mathrm{~g}$ nut meat $/ \mathrm{g}$ whole $)]$. Transporting the nuts back to the place of habitation requires $0.07 \mathrm{~min} / \mathrm{g}[1 /(12,500$ $\mathrm{g} / \mathrm{load} \times 0.15 \mathrm{~g}$ nut meat $/ \mathrm{g}$ whole $) /\left(10 \mathrm{~km}\right.$ walked $/\left(4.5 \mathrm{~km} \mathrm{hr}^{-1} \times 60\right.$ $\mathrm{min})$ )]. In total, $0.12 \mathrm{~min} / \mathrm{g}$ are required to gather mongongo nuts. Mongongo nuts are not the only plant foods gathered; averaging over all gathered foods, including mongongo nuts, Lee (1968) reports a collection rate for gathered foods of $0.09 \mathrm{~min} / \mathrm{g}$. If mongongo nuts comprised $52 \%$ of vegetable foods collected when the measure was made (Lee 1968), then nonmongongo vegetable foods must require $0.06 \mathrm{~min} / \mathrm{g}$ for collection.

During winter, Lee (1979) estimates the gathered diet of San to be $41 \%$ mongongo nuts and $59 \%$ other vegetable foods by weight. This would provide an average gathering rate of $0.08 \mathrm{~min} / \mathrm{g}$. Preparation of vegetable 
foods requires $0.32 \mathrm{~min} / \mathrm{g}(2.5 \mathrm{hr} / \mathrm{day})$ and the construction or repair of tools used in vegetable food collection requires $0.02 \mathrm{~min} / \mathrm{g}(18.8 \mathrm{~min} / \mathrm{day})$. Therefore, the total time involved in gathering plant foods is $0.42 \mathrm{~min} / \mathrm{g}$.

Most anthropological studies measure cropping rates in energy or nutrients per unit of time; however, this is confusing for a linear program model, where other constraints than time enter the model, since other parameters would have to be measured in terms of kilocalories (protein/ $\mathrm{kcal}$, digestive fill $/ \mathrm{kcal}$, etc.). The use of $\mathrm{kcal} / \mathrm{min}$ in most studies arises from the use of the contingency model (see above) and can easily be calculated from the dala presented here. Combining the above parameters, the feeding time constraint can be written as

$$
393 \min \geqslant 0.34 H+0.42 G .
$$

Digestive capacity is a potential constraint on human foraging because the quantity of food ingested each day cannot exceed the volume of the gastrointestinal tract times its turnover rate. If the human gastrointestinal tract is considered a constant flow system, the daily digestive capacity equals the stomach capacity for food (volumc less saliva-digestive juices) multiplied by the rate at which foods pass through the stomach. Passage through the gastrointestinal tract, rather than stomach emptying time, can be used because of the assumption of constant flow. A constant flow system provides the ability to process the greatest amount of food over an extended time period.

The human stomach has an average capacity of $700 \mathrm{ml}$ : a $1000-\mathrm{ml}$ stomach volume (Wohl and Goodhart 1968; Best 1952; Guyton 1969) less $300 \mathrm{ml}$ of saliva and digestive juices (Best and Taylor 1945). If gathered food is primarily vegetable matter, the food should pass through the digestive tract at a rate of 1.5 times/day, while meat has a passage rate of one time/day (Best and Taylor 1945). The digestive constraint (constant flow) is written as:

$$
700 \mathrm{ml} \geqslant \frac{H}{1}+\frac{G}{1.5}
$$

Records of people consuming massive quantities of food after a period of deprivation are often cited in the literature (Speth 1983; Speth and Spielmann 1983; Webster 1981). Digestive turnover rates can increase to 7.7 times/day for meat and 8.6 times for plant foods under conditions of nonconstant flow, such as periods of famine followed by feasting (Best and Taylor 1945). This added complexity could be used to construct a stochastic or risk averse analog to this deterministic digestive constraint. However, long-term food processing in the digestive tract is still greater 
under a constant flow system, and available data do not warrant a nonconstant flow model.

Nutritional requirements for humans can include a large range of nutrients, minerals, vitamins, and energy (Mann 1981). In designing the model for the !Kung, Lee's data $(1968,1979)$ suggest that two nutritional quantities might be limiting: energy and protein. For other hunter-gatherer groups, other nutritional requirements might also be important: e.g., fat (Mann 1981; Hayden 1981; Speth 1983; Speth and Spielmann 1983) and water (Silberbauer 1981a, 1981b). With only two food types (hunted and gathered foods), the number of nutritional constraints that can be operative (entering the solution) is very limited. Other nutritional factors may influence the selection of specific hunted and gathered species, but the model presented here examines the overall quantity of hunted vs gathered foods, not the specific species used.

!Kung energy requirements were computed using human metabolism values for high activity (Wohl and Goodhart 1968). These values were scaled by body weight to the 0.75 power to account for the smaller size of San, compared to Europeans. Using Lee's (1979) demographic data (proportion of the adult population composed of males, barren females, pregnant females and lactating females), an average adult San should expend approximately $1975 \mathrm{kcal} / \mathrm{day}$. This estimate is identical with Bentley's (1985) and a little lower than estimates of Leslie et al. (1984) for the !Kung.

Lce (1979) cstimates $3 \mathrm{kcal} / \mathrm{g}$ for cookcd meat. Dwyer (1983) provides an estimate for the Etolo of $2 \mathrm{kcal} / \mathrm{g}$ of cooked meat, while Hill et al. (1984) give values between 2.7 and $4.0 \mathrm{kcal} / \mathrm{g}$ of cooked meat (avg. 3.2 $\mathrm{kcal})$. Lee provides two estimates of the energetic value of mongongo nuts: $6 \mathrm{kcal} / \mathrm{g}(1968)$ and $6.4 \mathrm{kcal} / \mathrm{g}$ (1979); for other gathered vegetable foods he provides a value of $1 \mathrm{kcal} / \mathrm{g}$. If mongongo nuts comprise $41 \%$ of the gathered foods (Lee 1979), the energy content of gathered foods would be between 3.05 and $3.22 \mathrm{kcal} / \mathrm{g}$. Both sets of !Kung gathered food energy values will be used to determine if the differences might be important for the model's predictions. With these estimates of digestible energy, the energy constraint is written as

$$
1975 \mathrm{kcal} / \text { day } \leqslant 3.0 H+3.05 G \text { (or } 3.22 G \text { ). }
$$

Protein requirements are assumed to be the RDA (recommended daily allowance) cited by Lee (1968), $60 \mathrm{~g} /$ day. His value is somewhat greater than the $53 \mathrm{~g} /$ day computed using his demographic data and Davidson and Passmore's (1969) and Mann's (1981) data.

Lee $(1968,1979)$ estimates the protein content of meat to be $0.15 \mathrm{~g} / \mathrm{g}$ of cooked meat. Dwyer (1983) estimates it to be $0.21 \mathrm{~g} / \mathrm{g}$ of cooked meat. 
For protein content of mongongo nuts, Lee $(1968,1979)$ gives a value of $0.28 \mathrm{~g} / \mathrm{g}$ of nuts, and for other gathered foods $0.01 \mathrm{~g} / \mathrm{g}$ of food. With these data, the protein constraint is written as

$$
60 \mathrm{~g} / \text { day } \leqslant 0.15 H+0.12 G \text {. }
$$

\section{MODEL RESULTS}

\section{Solving the !Kung Model}

The linear program constraints for a lone !Kung adult are plotted in Fig. 2, and the energy-maximizing, protein-maximizing, and foraging time-minimizing strategies are presented. The energy and protein-maximizing diets are identical, meaning that the diet providing the greatest energy also provides the most protein. A $\chi^{2}$-contingency test can be used to compare the expected number of items ingested per day with the observed diet (Lee 1979). The number of items ingested was determined by dividing the mass of food ingested from hunting or gathering by the mean mass of a food item of that type, since a discrete measure is required for $\chi^{2}$ tests. All three predicted diets (Fig. 2) are significantly different from the observed bushman diet $(p<.05)$, and in all cases, the amount of hunting (meat) is underestimated. One should not expect this model to be correct since !Kung share food and not all !Kung forage; however, this represents the common form of most foraging models. Furthermore, this diet would not lead to any sexual division of labor, since each individual forages for his or her own food.

!Kung, as all hunter-gatherers, also provide food for nonforaging population members, primarily children. Consequently, the forager's con-

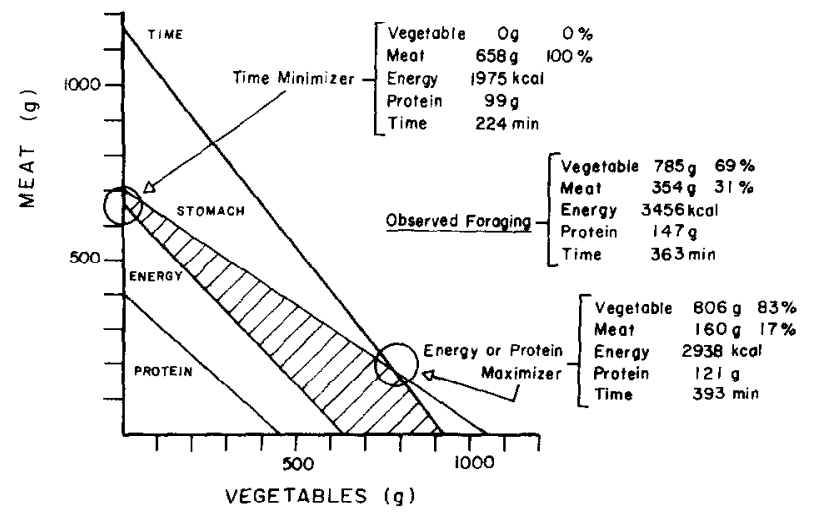

FIG. 2. The linear program solutions for a San's diet, if the San only forages for him or herself. 
straints, such as digestive capacity, must be directly modified by the presence of dependents. This is particularly important for humans compared to other mammals, since much of the food energy and nutrients provided to nonreproductives is directly ingested by them as hunted and gathered food, not as milk. The model cannot answer why children do not forage; this must be taken as a given. However, likely explanations are that children care for infants, permitting mothers to forage more (Brown 1970; Hurtado et al. 1985; Minge-Klevana 1980) or child mortality is reduced by not allowing them to forage.

Lee (1979) indicates that each adult !Kung forages for approximately 0.54 children or an additional body mass of $11.5 \mathrm{~kg}(\bar{X}$ nonnursing child weight of $21.3 \mathrm{~kg}$ ). If the digestive capacity is scaled by weight to account for these children, the digestive constraint becomes $879 \mathrm{~g} /$ day (Eq. 1). Since older children (60\% of children) do not forage but help to prepare vegetable food (Lee 1979), the cropping rate for gathering food in Eq. 2 is modified to $0.35 \mathrm{~min} / \mathrm{g}$, rather than $0.42 \mathrm{~min} / \mathrm{g}(0.08$ for collection +0.02 for toolmaking $+0.32 \mathrm{~min} / \mathrm{g} / 1.32$ individuals for preparation) in Eq. 2 . Energy (Eq. (3)) and protein (Eq. (4)) requirements are also increased by 0.54 to include the children.

The new constraint equations including nonforaging individuals and the model's solution(s) are presented in Fig. 3. Using $\chi^{2}$-contingency tables, the energy/protein-maximizing diet (Fig. 3) is not significantly different from the observed diet, while the time-minimizing diet is different. This indicates that the !Kung may maximize their intake of nutritional components, rather than minimize foraging time.

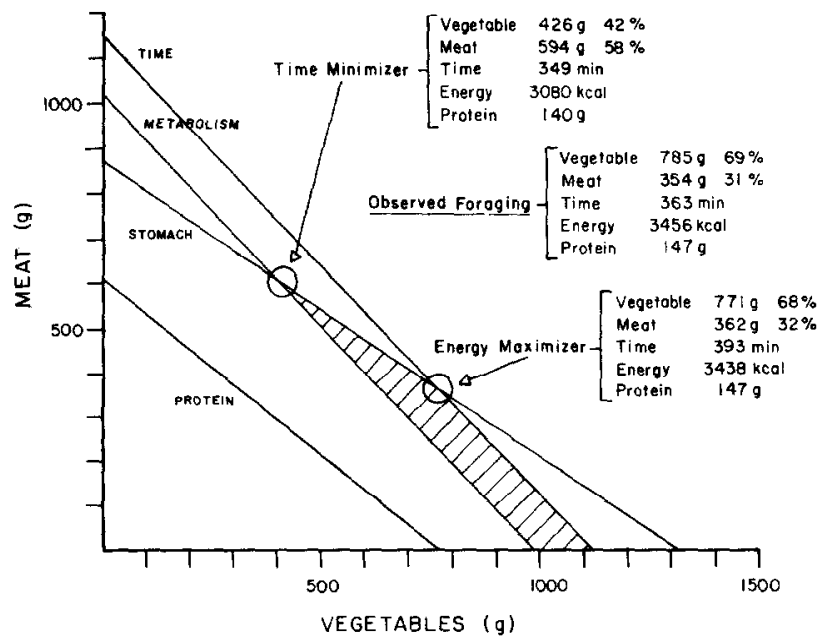

Fig. 3. The linear program solutions for a San's diet, if the San not only forages for him or herself but also for dependents. 
The surplus energy or protein ingested might be used for growth, fat storage or extra activity (Lee 1979:272), and the energy requirements do not include the specific dynamic action needed to metabolize protein or the metabolic increases at thermal conditions different from thermal neutrality. Finally, the surplus intake would result in a fat deposition of 30 $\mathrm{g} / \mathrm{day} /$ person $(358 \mathrm{kcal}$ surplus/person $\div 7.7 \mathrm{kcal} / \mathrm{g}$ fat $)$. 33 days of foraging at this level would be required to store $1 \mathrm{~kg}$ of fat, if all the surplus energy were used in fat deposition. Given that the model parameters are estimated for a time of year when food is not scarce, this is a likely use for surplus intake.

To examine the potential sexual division of labor, let us assume that women only gather foods, and men always hunt, gathering only if women cannot gather the optimal amount of gathered food in their foraging time. The !Kung optimal diet is obtainable with this division of labor and the only condition is that men must prepare their own gathered foods (primarily crack mongongo nuts) which is observed (Lee 1979). In this case, men and women would partake in relatively equal amounts of total work, which Lee (1979:278) found. The predictions of the model with this division of labor would have women supplying $68 \%$ of the food in $85 \%$ of the time a man spends acquiring food. Lee (1982) reports respective values of $56 \%$ and $78 \%$, averaged over the entire year. Therefore, the optimal diet is obtainable given the observed sexual division of labor.

It is always satisfying to find substantial agreement between a model's predictions and observations from the "real" world; however, one must always ask how sensitive the apparent concordance is given potential errors in parameter estimates. Sensitivity was investigated by varying each of the constraint equations in Fig. 3 by $\pm 10 \%$ and determining the changes in the diet predictions (Table 2). Unfortunately, the model's diet

TABLE 2

The Effects on Gathered Food Diet Proportions That Are Predicted with $\pm 10 \%$ Changes IN THE SAN Foraging MODEl's CONSTRaints

\begin{tabular}{ccc}
\hline & $10 \%$ Increase & $10 \%$ Decrease \\
\hline Gut & $32.0 \%$ & \\
Diet & $+0.3 \%$ & $33.0 \%$ \\
Energy & $+5.6 \%$ & $-0.2 \%$ \\
Protein & & $-5.8 \%$ \\
Time & $30.0 \%$ & $36.0 \%$ \\
Diet & $+9.8 \%$ & $-9.7 \%$ \\
Energy & $+4.2 \%$ & $-4.4 \%$ \\
Protein & & \\
Energy & $62.0 \%$ & $65.0 \%$ \\
Diet & $-1.2 \%$ & $-8.6 \%$ \\
Protein & & \\
\hline
\end{tabular}


predictions can dramatically change with $10 \%$ changes in parameter values (Table 2).

The constraint values that are most sensitive to changes are the energy parameters. A $10 \%$ change in the energy constraint can account for a $60 \%$ or more change in diet proportions. Even more striking is the effect of changes in the ratio of energetic payoffs $(3 \mathrm{kcal} / \mathrm{g}$ for meat to $3.05 \mathrm{kcal} / \mathrm{g}$ for vegetable foods). A decrease of $1.6 \%$ in the ratio can change the energy-maximized diet in Fig. 3 from $68 \%$ gathered foods to $100 \%$. This can be observed by using Lee's (1979) larger energy value for mongongo nuts (gathered foods with $3.2 \mathrm{kcal} / \mathrm{g}$ ), which would predict the !Kung to be protein maximizers unconcerned with energy, not protein and energy maximizers as argued above. Changes in the protein payoff ratio are not as sensitive; this ratio must decrease by $20 \%$ before any change can be observed in the protein-maximizing diet.

To have the energy/protein-maximizing diet identical with the timeminimizing diet, the necessary constraint changes are larger than discussed above. A $23 \%$ decline in the digestive constraint (e.g., $676 \mathrm{~g} /$ day vs $879 \mathrm{~g} /$ day), an $11 \%$ decline in the foraging time constraint (e.g., 340 $\mathrm{min} /$ day vs $393 \mathrm{~min} /$ day), a $12 \%$ increase in the energy constraint ( 3080 $\mathrm{kcal} /$ day vs $3438 \mathrm{kcal} /$ day), or a $245 \%$ increase in the protein constraint $(147 \mathrm{~g} /$ day vs $60 \mathrm{~g} /$ day $)$ are required. This indicates that distinguishing the energy and protein-maximizing diets from the foraging time-minimizing diets is very clear.

What does this high sensitivity in the model's predictions imply? This is hard to ascertain because the parameter values used in the model's construction were not presented with variance, standard deviation or standard error estimates in the source studies. Consequently, one cannot assess how likely a $10 \%$ error in the parameter estimates might be. Also, the absence of any set of error measurements for the model's parameters does not permit the use of more advanced sensitivity analyses, such as Monte Carlo simulation. More advanced techniques might give less extreme, as well as more realistic, sensitivity estimates.

Obviously, one needs to accept the model with caution since widely varying predictions might occur with variations in parameter values. One way to avoid this problem is to test the model repeatedly. If repeated solutions of the model agree with observed diets then our confidence is enhanced even though each specific prediction may be very sensitive to parameter changes.

\section{Modelling Diets of Other Hunter-Gatherers}

The diet model developed above for a !Kung group can be used to make dietary estimates for other hunter-gatherer groups by changing pa- 
rameter values and using different nutritional constraints for each particular group of people.

G/wiSan. Based upon the diet proportions provided by hunting and gathering, the observed !Kung diet is very similar to diets observed for G/wi San during the same time period (Lee 1968). This suggests a similar foraging strategy (common model) for both groups (Table 3).

!Kung in fall, a time of peak mongongo production, live near mongongo groves and seem to harvest mongongo fruit slightly more rapidly (approx $0.31 \mathrm{~min} / \mathrm{g}$ : Lee 1979) than used in the model for mongongo nuts in winter. Decreasing the gathering cropping rate by the above estimates from Lee (1979), the predicted diet is observed to change. Again, comparing the observed and predicted diets, one can conclude that the diet leads to maximum energy/protein intake (Table 3).

$\neq$ Kade San (Tanaka 1976) have a very different diet from the !Kung or G/wi (Table 3). Tanaka (1976) suggests that the $\neq$ Kade have to consume more vegetable food to satisfy water requirements, because free water is not available. This would lead to an additional nutritional constraint, water, which modifies the digestive and time constraints. $\neq$ Kade require $1800 \mathrm{~g}$ of water/day squeezed from tubers which are $95 \%$ water by weight (Tanaka 1976). Since the tuber is also eaten, the stomach constraint (Eq. 1) has to be reduced to account for tuber consumption needed for water intake $[(1800 \mathrm{~g} / 0.95$ water $\times 0.05$ vegetable matter $\times 1.54$ individuals $/$ adult $\times 0.67$ turnover rate of vegetable matter $)=97.7 \mathrm{~g}$ reduction], which is also added to the predicted diet. Also, the feeding time con-

TABLE 3

Predicted and ObSeRved Diets for Different Hunter-Gatherer Populations USing a LiNear Program Foraging Model Solved for EnERgy MaXimization

\begin{tabular}{|c|c|c|c|c|c|c|c|c|c|c|}
\hline & \multicolumn{2}{|c|}{$\begin{array}{l}\text { !Kung }^{a} \\
\text { Winter }\end{array}$} & \multicolumn{2}{|c|}{$\begin{array}{c}\text { !Kung }^{a} \\
\text { Fall }\end{array}$} & \multicolumn{2}{|c|}{$/ G w i^{b}$} & \multicolumn{2}{|c|}{$\neq \mathrm{Kade}^{c}$} & \multicolumn{2}{|c|}{ Achéd $^{d}$} \\
\hline & $\mathbf{P}$ & o & $\mathbf{P}$ & $\mathrm{O}$ & $\mathbf{P}$ & 0 & $\mathbf{P}$ & $\mathrm{O}$ & $\mathbf{P}$ & $\mathrm{O}$ \\
\hline Meat (\%) & 32 & 31 & 94 & 90 & 32 & 30 & 18 & 16 & 83 & 80 \\
\hline Vegetables (\%) & 68 & 69 & 6 & 10 & 68 & 70 & 82 & 84 & 17 & 20 \\
\hline Time (min) & 393 & 363 & 393 & - & 393 & - & 369 & $\sim 300$ & 362 & $\sim 362$ \\
\hline Intake ( $g$ /ind) & 746 & $\sim 740$ & 816 & - & 746 & - & 1052 & $\sim 947$ & 930 & $\sim 947$ \\
\hline
\end{tabular}

${ }^{a}$ Lee (1979).

${ }^{b}$ Lee (1968).

c Tanaka (1976).

${ }^{d}$ Hawkes, Hill and O'Connell (1982); Hill et al. (1984, 1985); Hurtado et al. (1985). Cropping rate for meat $=0.34 \mathrm{~min} / \mathrm{g}$ killed. Cropping rate for gathering $=0.63 \mathrm{~min} / \mathrm{g}$ collected (estimated in terms of weight consumed after water is extracted and less water mixed with honey: $0.36 \mathrm{~min} / \mathrm{g} \div 0.6$. Foraging time averaged for men and women $=362 \mathrm{~min} /$ day. Dependent/adult $=0.47$. 
straint (573 $\mathrm{min} /$ day: Tanaka 1976) has to be reduced to account for tuber collection and preparation (Eq. 2) $(1800 \mathrm{~g} / 0.95$ water $\times 1.54$ individuals/ adult $\times 0.07 \mathrm{~min} / \mathrm{g}=204 \mathrm{~min} /$ day reduction). Using these modifications to account for an additional constraint, water requirements, the $\neq$ Kade appear to maximize their energy or protein intake (Table 3).

Peruvian Aché appear to have different cropping rates, foraging times, and numbers of dependents per adult (Hawkes et al. 1982; Hill et al. 1984, 1985; Hurtado et al. 1985) than the !Kung. Solving the diet model (Table 2) for foraging by these people when away from their mission homes and not carrying any mission foods, the Aché appear to forage as energy/protein maximizers. This is observed even though the Aché can get food at the mission (see Hill et al. 1985 for justification). Using the same rules of sexual division of labor employed for the !Kung, we find that Ache females are predicted to provide only $17 \%$ of the foods. Hurtado et al. (1985) find that females provide on average $14 \%$. The solution for the optimal diet is only possible given a division of labor in which women do all of the food preparation, which is observed (Hurtado et al. 1985).

The close agreement between the predicted and observed diets in Table 3 is very suggestive of the utility of the foraging model and increases confidence in the model even with its high sensitivity. The model not only captures the qualitative aspects of hunter-gatherer foraging choices but quantitatively predicts intakes of different foods and division of labor by sex. Nonetheless, the main value of the foraging model may be to point out the need for more effort in measuring nutritional/feeding parameters in anthropological studies to develop better models.

\section{Hunting vs Gathering from around the World}

If we assume that the foraging model describes the diet choices of hunter-gatherers, it would be useful to determine how the constraint equations might change in different environments and how this might affect diet choice. Obviously, different environments will have different thermal conditions which might change the amount of time a human forager has to seek foods. Humans with their ability to make sheiters and clothing may minimize these differences, which may be seen in the relatively constant work times demonstrated by hunter-gatherers (Table 4). Therefore, let us assume for simplicity that the daily work time is a constant (the !Kung value of $420 \mathrm{~min} /$ day less household work, $27 \mathrm{~min} / \mathrm{day}$ ). Also, assume that the number of dependents per adult does not vary from the !Kung value, 0.54 /adult. With these overly simple assumptions and knowledge of how cropping rates change with the average abundances of different foods in different environments, some very crude approxima- 
TABLE 4

TIME SPENT IN FoOD ACQUiSITION AND WORK ${ }^{a}$ BY HUNTER-GATHERERS

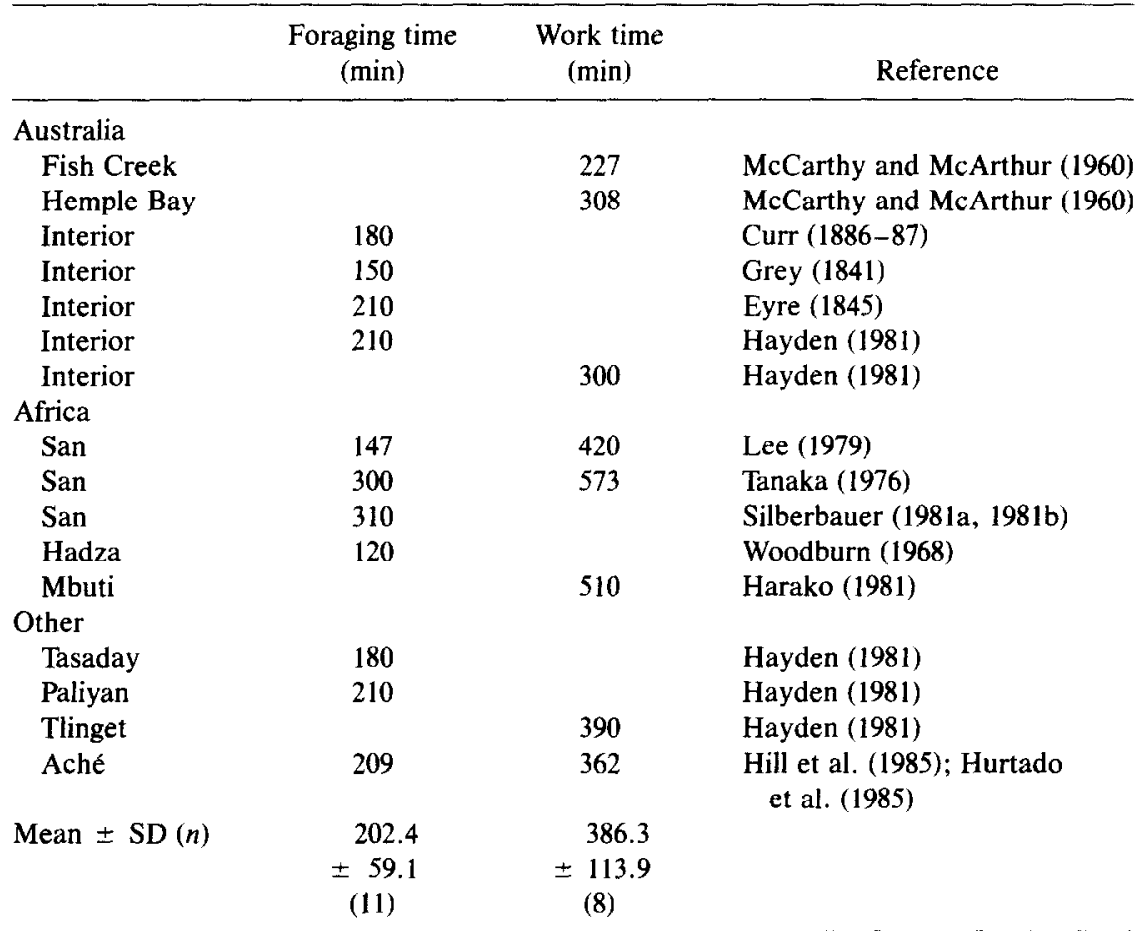

${ }^{a}$ Work is defined as the sum of time spent acquiring food, preparing it, making tools, and other survival related activities.

tions about how hunter-gatherer diets might vary in different environments can be made.

Obviously, the above assumptions are too simple and do not take into account localized food abundances that people might seek and utilize. Nonetheless, we can use this approach to determine how much of the observed diet variation might arise from average environmental differences. If general patterns like this cannot be found, then we are left with the analysis of specific cases.

Food abundances, both vegetable and animal, should increase with the primary production of the environment. Gathering (primarily referring to vegetable foods) can be readily seen to be a function of plant production. Hunting success (primarily for herbivorous animals) should be related to animal abundance which also should be a function of plant production. Therefore, hunter-gatherer cropping rates might be related to environmental primary production.

Using Leith's (1975) map of global primary production, the average 
primary production for different parts of the world can be estimated. In grasslands, most of the primary production is available for consumption by either the hunter-gatherers or their animal prey, since little of the vegetation is composed of structural components (wood, bark, etc.). Unlike grasslands, forests have large portions of their primary production that cannot be consumed by a gatherer or a hunter's prey because of inedible structural components. Therefore, the primary production of forests must be reduced to reflect the portion that is usable: low fiber content (leaves, fruit, new twigs, etc). Using data available for the portion of primary production provided by relatively low fiber material in forests (Table 5), a regression was developed to convert overall forest production into usable production.

To relate these primary production estimates to hunter-gatherer cropping rates, the gathering and hunting rates must be broken down into their component parts (acquisition, preparation, and tool making), because preparation and tool making are independent of food availability. Therefore, acquisition time is all that changes with food abundance. This

TABLE 5

VAlues for the Proportion of Forest Primary Production IN THE UNDERSTORY Representing the Production Available to Man or His Prey Animals

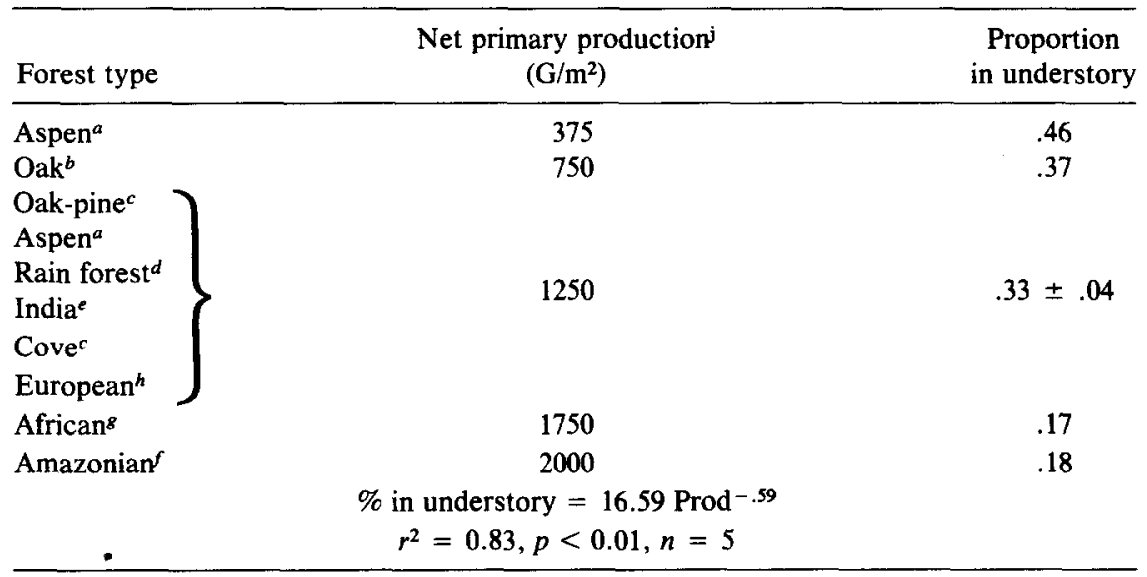

a Bray and Dudkiewicz (1963).

b Ovington (1962).

$c$ Whittaker (1970).

a Odum (1970).

- Garg and Vyas (1975).

${ }^{f}$ Klinge et al. (1975).

${ }^{8}$ Malaisse et al. (1975).

${ }^{h}$ Duvigneaud and Denaeyer-DeSmet (1970).

${ }^{j}$ Leith (1975). 
is called the functional response in ecology (Holling 1965; Hassel 1978) and will be modeled in this paper as a simple inverse function of primary production.

Since changes in the abundance of gathered foods only impact upon the actual acquisition of the food, the observed time for !Kung food preparation and tool making, $0.23 \mathrm{~min} / \mathrm{g}$, was used for all people. Dividing the remaining portion of the cropping rate for the !Kung (Lee 1979), Aché (Hawkes et al. 1982; Hill et al. 1984), Alywara (O'Connell and Hawkes 1981) and Cree (Winterhalder 1981b) by the primary production of their environments from Leith's (1975) global map of primary production, a functional response can be estimated (Fig. 4a):

$$
C_{G}= \begin{cases}0.23+41.0 / p & \text { if } p<425 \mathrm{~g} / \mathrm{m}^{2} \\ & \left(N=4, r^{2}=0.99, p<0.05\right) \\ 0.34 & \text { if } p \geqslant 425 \mathrm{~g} / \mathrm{m}^{2}\end{cases}
$$

where $C_{G}$ is measured in $\mathrm{min} / \mathrm{g}$ of food ingested and $p$ is the environment's primary production $\left(\mathrm{g} / \mathrm{m}^{2}\right)$. This function is constructed with the assumption that $C_{G}$ has a minimum value when primary production exceeds $425 \mathrm{~g} / \mathrm{m}^{2}$, which is the production value for the !Kung environment. This limit for $C_{G}$ arises since Lee (1979) claims that the !Kung can acquire vegetable foods (primarily mongongo nuts) as fast as they can pick them up and place them in their carrying bags during the period of his study (i.e., search is negligible). The distance travelled to gathering sites was estimated to be an average for all the campsites (Lee 1979), so this value is considered a constant.

From the !Kung data on hunting it was found that $0.13 \mathrm{~min} / \mathrm{g}$ is required for meat preparation and tool construction (Lee 1979). This quantity was subtracted from the hunting cropping rates to estimate the meat acquisition rates. Using the meat acquisition rates for the !Kung (Lee 1979), Bisa (Marks 1976), Etolo (Dwyer 1983), Cree with premodern technology (Winterhalder 1980, 1981b), Mbuti (Harako 1981), Australian Aborigines (Gould 1981), Yanamano (Hames 1979), and the Aché (Hawkes et al., 1982), and their respective environment's average primary production from Leith's (1975) map, the functional response can be written as $\mathrm{min} / \mathrm{g}$ (Fig. 4B):

$$
C_{H}=0.28+25 / p \quad\left(N=9, r^{2}=0.66, p<0.05\right) .
$$

Both Eqs. (5) and (6) are based on scant data. This is particularly true since the studies from which the cropping rates were taken often did not measure the parameters in the same way. These data, however, do permit a crude assessment of how environmental differences impact on hunting vs gathering and indicate the potential utility in investigating how acqui- 


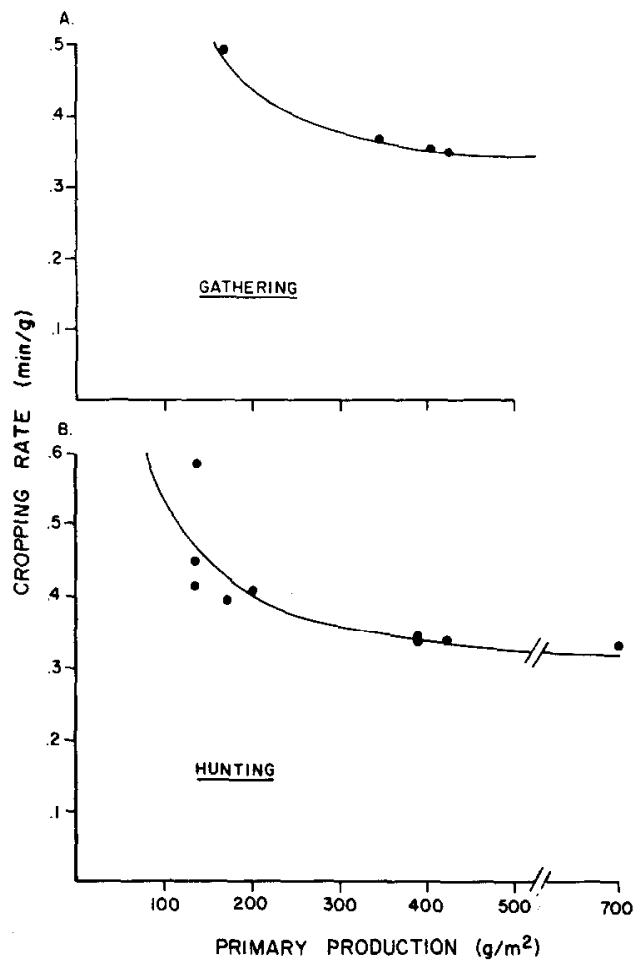

Fig. 4. The cropping rate data for the hunter-gatherers presented in the text are plotted against their environment's average primary production.

sition rates change in different environments and influence hunter-gatherer diets (Binford 1980, 1985; Hayden 1981). Using the primary production values for forest and grassland areas in Eqs. (5) and (6), the linear program model can be solved for the diets which maximize a huntergatherer's energy/protein intake or minimize foraging time.

Using Leith's (1975) map, the primary production for different areas inhabited by the hunter-gatherers listed by Lee (1968) and Hayden (1981) can be plotted against their observed diets and compared with the model's predictions (Fig. 5). The diet is presented as the proportion of food mass provided by hunting: this includes fish consumption, but not shellfish which are recorded as being gathered in these compilations. This combination of foods into categories in the compilations is misleading and leads to some confusion. Another potential bias in these data arises from a nonrandom sample of hunter-gatherers (Ember 1978) which may not give an adequate representation of hunter-gatherer diet choices, but the data provides a starting point and some interesting patterns do emerge. 


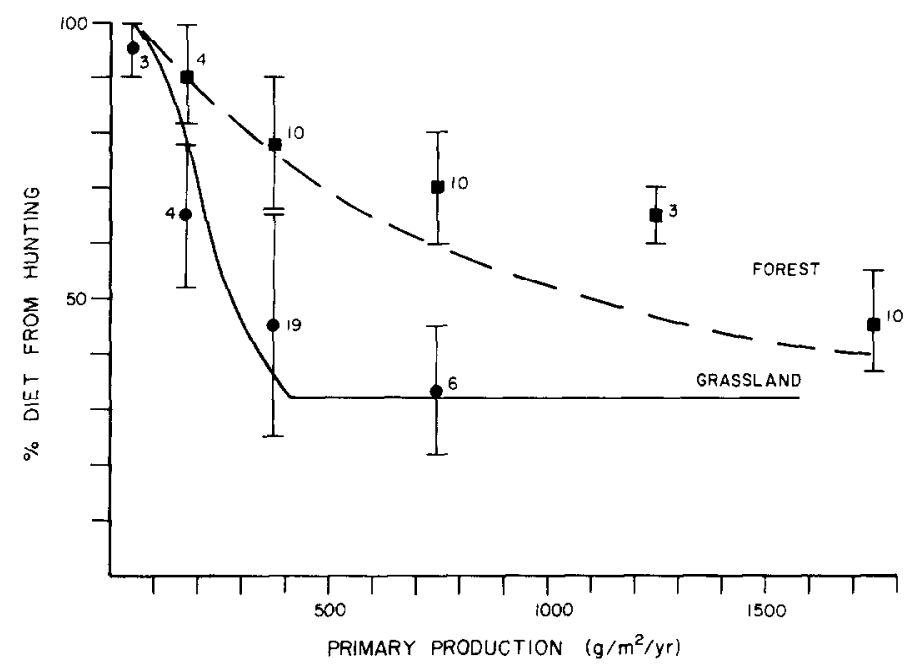

FIG. 5. The graph illustrates how the proportion of diet from hunting changes with primary production in the environment. ( $\boldsymbol{\sigma}$, Forest data; $\boldsymbol{O}$, grasslands). Each point represents a mean with the standard deviation and sample size for observed hunter-gatherer diets. The linear program diet model's predictions for proportion of diet from hunting are also plotted for forests (---) and grasslands (-) of different primary productivities.

Hunting is found to decrease in importance as primary production increases in both grasslands and forests, although the change occurs more rapidly in grasslands (Fig. 5). It appears that actual usable primary production may decrease faster for forest hunter-gatherers than predicted by the regression in Table 5, since the amount of hunting does not decrease as rapidly as predicted (Fig. 5). This means that hunting should be more important in forests than grasslands, on average. Finally, the model tends in general to underestimate the importance of hunting except at low primary productions; this will be discussed further with food storage. The predicted pattern of changes in hunting vs gathering have been reported by others (Hayden 1981; Binford, 1980, 1985; Freeman 1981), but the model provides a quantitative representation that might be used to interpret prehistoric environments.

The predicted energy/protein-maximizing diets agree quite well with the average observed values (Fig. 5: grassland, $r^{2}=0.98$; forest, $r^{2}=$ 0.88 ). A comparison with the time-minimizing diets predicted from the model is not as good (grassland, $r^{2}=0.80$; forest, $r^{2}=0.60$ ). Given the crude data, however, one cannot statistically distinguish between energy/ protein maximization or time minimization for the hunter-gatherers.

One should notice the large observed variances (Fig. 5), these can arise from several factors. First, sites chosen by hunter-gatherers for foraging can be greater or less than the average primary productivities used in the 
model. Second, the cropping rates and food nutritional values can vary between environments; e.g., the Aché acquire large quantities of raw food but these contain large amounts of water (honey, palm starch, etc.), requiring much processing. Third, productivity of aquatic environments is not included. Therefore, this general model is a crude approximation which shows promise for further investigation.

The feeding model has implications for several other aspects of hunter-gatherer life. First, greater participation by children in foraging or fewer children than observed for the !Kung would be required in grasslands with productivities below $250 \mathrm{~g} / \mathrm{m}^{2}$ and in forests with productivities below $900 \mathrm{~g} / \mathrm{m}^{2}$. Energy intakes at these lower productivities satisfy individual requirements $(1975 \mathrm{kcal} /$ day $)$ but do not satisfy the !Kung family requirements ( $3080 \mathrm{kcal} / \mathrm{day})$ (Fig. 6A). This indicates that family organization and size may be, at least in part, determined by the foraging environment.
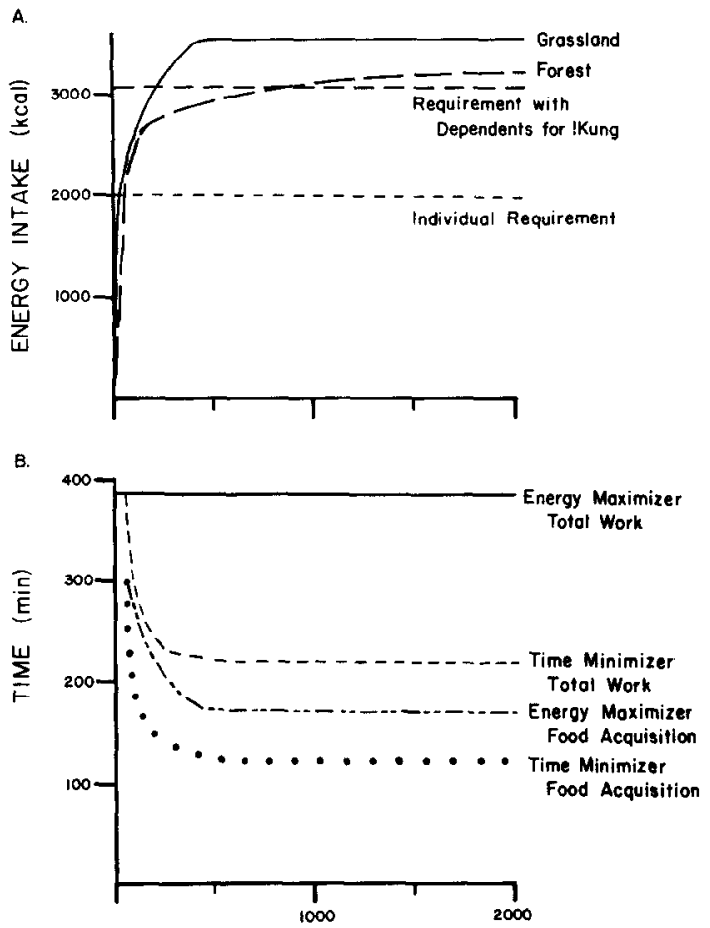

USABLE PRIMARY PRODUCTION $\left(\mathrm{g} / \mathrm{m}^{2}\right)$

FIG. 6. Various foraging parameters, as predicted by the linear program diet model at different primary productions. (A) Energy intake, if the hunter-gatherer is an energy maximizer, is plotted for comparison to energy requirements for individuals and individuals with the !Kung's number of dependents. (B) The way that total work and food acquisition times should change with usable primary production, as predicted by the foraging model. 
Values observed for foraging and total work times for hunter-gatherers (Table 5) can be compared to those predicted by the model. An average value of $386 \mathrm{~min} /$ day \pm 114 for all work is observed, while $202 \mathrm{~min} /$ day \pm 59 is spent in food acquisition. The average times for total work and food acquisition can be predicted by the model for the range of productivity values observed in grasslands and forests. $393 \mathrm{~min} /$ day \pm 0 for all work and $192 \mathrm{~min} /$ day \pm 39 for food acquisition are predicted by the energymaximizing solution to the foraging model (Fig. 6B). The times predicted for time minimization are $235 \mathrm{~min} /$ day \pm 44 for all work and $143 \mathrm{~min} /$ day \pm 44 for foraging. Neither the energy-maximizing or time-minimizing time estimates are significantly different from the observed time values, but the energy-maximizing values are closest to the observed values.

Using the criteria for the sexual division of labor presented above, all the predicted diets are feasible. However, to obtain the diets that are primarily hunted foods at low primary productions, women must help with butchering and transport, and to obtain the diets that are primarily gathered foods at high primary production, men must aid in the preparation of gathered foods. Figure 7A shows how the relative food acquisition times for the sexes should change in different environments. A comparison of how sexual division of labor is predicted to change with diet is presented and compared with observed patterns (Hayden 1981) (Fig. 7B) indicating close agreement.

\section{DISCUSSION}

\section{Present Day Hunter-Gatherers}

The foraging model as presented above suffers from incompete, as well as insufficient, data. The results, however, are tantalizing in terms of the potential to develop a quantitative model of hunting vs gathering as the model may help to explain the allocation of time, quantities of food consumed and the sexual division of labor required by these two modes of subsistence.

The analysis using the linear program model indicates that it, rather than the contingency model of foraging as commonly developed for hunter-gatherers, may be the more appropriate model. Furthermore, the development of the linear program model indicates that certain measures of hunter-gatherer foraging activity might be measured and/or presented differently in anthropological studies. This means that to progress beyond the qualitative tests of optimal forging for hunter-gatherers, the models being employed and types of data being collected must be reevaluated. The model provides a means of comparing the relative value of hunting vs. gathering for a forager. Gathered foods are found to be 


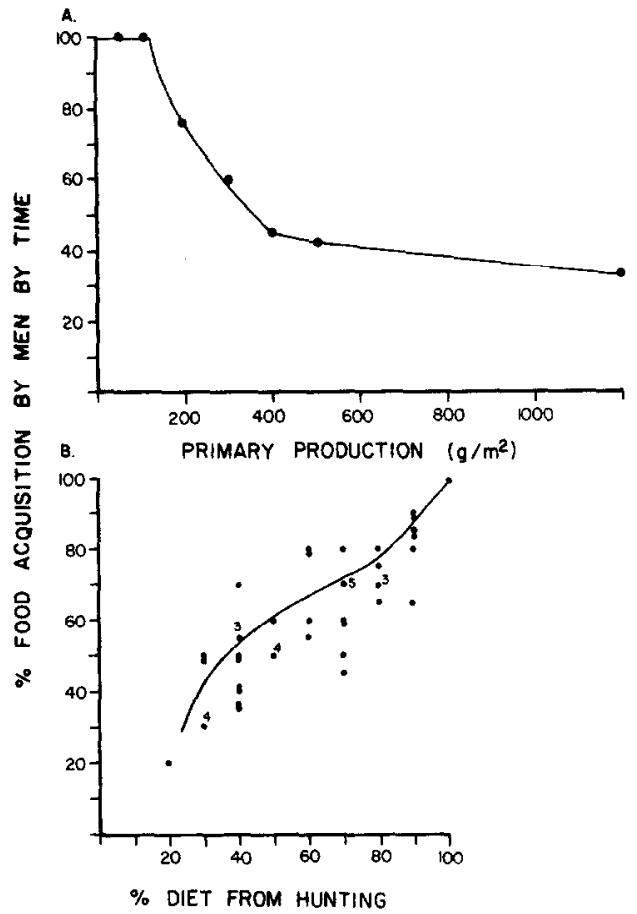

FIG. 7. The rules for sexual division of labor presented in the text are used to determine division of labor for a given diet predicted by the model for each average environmental primary production (A). For grasslands this primary production is the observed value; for forests the primary production is reduced by the fraction that is not usable (see text). The observed division of labor is plotted against the observed diet for 52 hunter-gatherers (Hayden 1981) (B). The line is the predicted relationship from the model.

acquired more rapidly than hunted foods, as is commonly cited (Lee 1979). However, because of the greater time needed for preparing gathered foods for consumption than hunted foods, the total time needed to crop a unit of consumable food is greater for gathered foods. On the other hand, gathered foods do not use up as much of a human's digestive capacity, as do hunted foods.

By describing hunted and gathered foods in this broader context we find that both Lee's $(1968,1979)$ and Harris' $(1977,1979)$ arguments are correct. Lee claims greater efficiency in exploiting gathered foods; this argument is true on the basis of digestive capacity. Harris argues that meat is more efficiently exploited, which is true based upon time constraints. Therefore, it is the trade-off between these differences in efficiency values that determines the diet. This trade-off is not built into other foraging models for hunter-gatherers.

If hunter-gatherers are consistently energy and protein maximizers as 
indicated by the analysis, what is implied about their way of life? These findings are a strong indication that hunter-gatherer populations might be either energy or protein limited. Hawkes et al. (1985) come to a similar conclusion and Hayden (1981) finds 11/18 hunter-gatherer groups demonstrating nutritional stress. These data question the notion that huntergatherers maximize their leisure time (Sahlins 1968, 1972, 1976; Leacock and Lee 1982), because food is not in short supply. Obviously in the models presented here, the amount of feeding time for the time constraint is critical to this conclusion. To better document that foraging time is truly limiting, thermal physiology studies and models need to be better developed.

Because the hunter-gatherers that are available today for study come from a narrow range of environments and their habits are being rapidly changed by governmental policies and economics, a quantitative model that can examine other environments and provide predictions would be very useful. By developing such a foraging model and verifying it using the limited historical accounts, our knowledge of hunter-gatherer adaptations can be expanded.

A quantitative model also permits us to examine premises for which data may be difficult to acquire, and to determine how important they potentially may be. This is particularly true for questions about risk and food storage, interpreting prehistoric environments to gain an understanding of hominid evolution, and for questions about how foraging might change human fitness.

\section{Risk of Going Hungry and Food Storage}

A general graphical representation of the linear program foraging model appears in Fig. 8A. This model, as pointed out initially, does not include any risk of going hungry because the probabilities of failing to find food are not considered, i.e., the model is totally deterministic. How can this risk be built into the model? Whether the risk of going hungry arises from the vagaries of success in finding food or regular seasonal shortages of food, the changes in diet choice can be examined using the model.

If hunter-gatherers are faced with the vagaries of finding food on a day-to-day basis (risk sensitive foraging sensu Caraco 1980a, 1980b, 1981), then the deterministic model, presented above, must have its foraging time constraint modified. The time constraint is reduced using the variances in the cropping rates for hunting and gathering (Fig. 8B). This variance might be the poorest observed cropping rate or the $95 \%$ confidence interval; it is a representation of the worst a forager might be expected to do. If any nutritional constraint (e.g., energy, protein, etc.) 


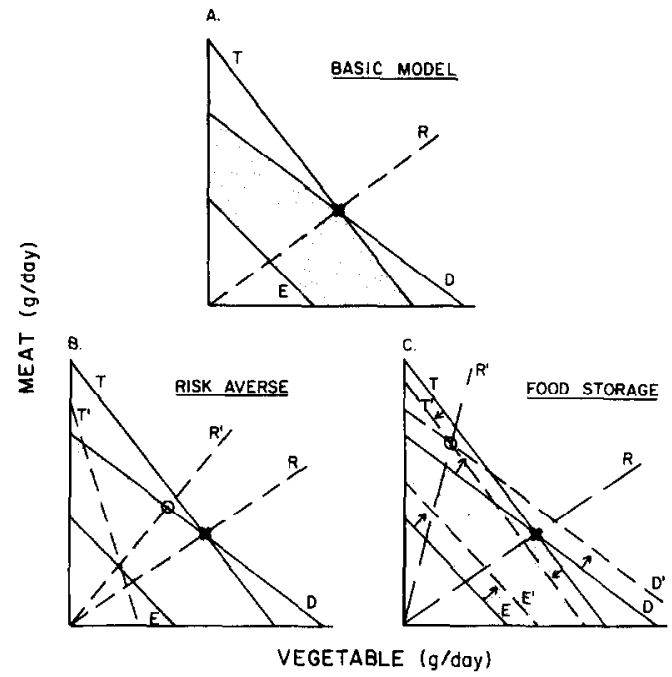

FIG. 8. A general graphic representation (A) of the linear program model. $T$ is the foraging time constraint, $D$ is the digestive constraint, and $E$ is the energy requirement constraint. The shaded region represents the set of possible diet choices and the star is the energy/protein-maximizing diet. The line marked with an $R$ has a slope representing the energy/protein-maximizing diet proportions. (B) Presents a modification of the model (see text) for risk averse foraging. (C) Presents a modification for food storage (see text). Dashed lines marked with a prime and letter represent modified constraints. The new predicted diet is circled and the new diet proportions are represented by the $R^{\prime}$ line's slope.

cannot be satisfied with the amount of food that can be ingested at the deterministic model's optimal diet proportions given this new time constraint and the new time constraint intersects the nutritional constraint (Fig. 8B), then the hunter-gatherers will modify their diet from that computed in the deterministic case.

The new diet will be the ratio of hunting to gathering represented by the slope of a line through the origin to the intersection of the new time line and the nutritional constraint. This is a risk sensitive diet (sensu Caraco 1980a, 1980b, 1981), which minimizes the chances of the huntergatherers failing to satisfy their nutritional needs. If the modified time constraint does not intersect the nutritional constraint (it is either above or below the modified time line), the predictions from the deterministic model are unchanged.

If hunter-gatherers are risk sensitive then either hunting or gathering will increase depending upon a set of inequalities. $H$ and $G$ are the quantities of food acquired by hunting and gathering in the deterministic solution, $V_{H}$ and $V_{G}$ are the variances in hunting and gathering cropping rates, and $Q_{H}$ and $Q_{G}$ are the nutritional values of food acquired by hunting and gathering (e.g., energy if the hunter-gatherers are energy 
maximizers). With the above values, the inequalities that determine diet changes with risk sensitivity can be defined
(a) if $\frac{H-V_{H}}{G-V_{G}}>\frac{Q_{H}}{Q_{G}}$, then hunting increases,
(b) if $\frac{H-V_{H}}{G-V_{G}}<\frac{Q_{H}}{Q_{G}}$, then gathering increases,

and

(c) if $\frac{H-V_{H}}{G-V_{G}}=\frac{Q_{H}}{Q_{G}}$, the case is undefined.

$V_{H}$ should usually be greater than $V_{G}$ due to the vagaries of finding and stalking animals (Mann 1981; Hayden 1981), but without knowing $H, G$, $Q_{H}$, and $Q_{G}$, no general conclusions can be made.

The added complexity of the risk sensitive model is beyond the data of most hunter-gatherer studies. Nonetheless, data on the Ache (Hill et al. 1984, 1985; Hawkes 1982; Hurtado et al. 1985) indicate that these groups do not satisfy the conditions necessary for risk sensitive foraging to be observed. Although risk sensitive foraging models may have applicability to hunter-gatherers, how common risk sensitive foraging might be cannot be determined or is not worth addressing without expanded data.

If food is seasonally unavailable or very rare (e.g., northern winters), storage might be important. Food storage can be built into the model by varying three constraints: foraging time, digestive capacity and nutritional requirements. The foraging time line will decrease due to the time needed to prepare foods for storage, digestive capacity will increase by the fraction of days with food unavailable/days with food available since food is now collected to be processed over a longer time period and the nutritional requirement(s) must also be increased by this new time frame. With these new constraints (Fig. 8C), a deterministic diet model that includes food storage can be constructed. Again the data for hunter-gatherers are not adequate to solve this modified model.

Several general comments, however, can be made about food storage given the model parameters presented above. First, if the product of the multiples reflecting the time constraint's decrease and digestive capacity's increase exceed a value of approximately 1.4, food storage is not profitable. Therefore, as the period of reliance on stored foods approaches $40 \%$ of the period for foraging or food preparation for storage increases cropping rates by $40 \%$, food storage will no longer be profitable for the entire period of scarcity. Hayden (1981) argues that food storage is very time consuming, especially in warmer climates; this may in part be 
the reason for less food storage among hunter-gatherers inhabiting these regions.

Second, if the times needed to store hunted and gathered foods are comparable, food storage should lead to diets higher in hunted food (including fishing) than expected from the model without food storage. This arises because hunted foods have on average lower cropping rates than gathered foods (see the general model above). It is possible that food storage might be the reason that the diets predicted by the general model tend to be lower in hunted foods at intermediate and high primary productivities than observed. At low productivities hunting is the major means of food acquisition regardless of whether food storage is expected. Therefore, food storage is an additional, but certainly not major, consideration with which future hunter-gatherer studies and models may need to deal.

\section{Extrapolating to Other Environments and Times}

A major reason that anthropologists and archaeologists study human foraging strategies is to determine how humans solve the foraging problems that they face today and to ask how these same problemsolving abilities might lead to different adaptations in past environments. As an example of the possible utility of this approach, the general diet analysis for hunter-gatherers in environments of differing productivities can be used to ask: under what circumstances might hunting and gathering be abandoned for either agricultural or pastoral life ways? This question can be examined by including farming or pastoralism as a third food source in the linear program model.

With this third food source, the foraging model can be algebraically solved to find the necessary cropping rate for agriculture/pastoralism that would be needed to replace either hunting or gathering with agriculture/ pastoralism given a set of hunting and gathering cropping rates. One mode of subsistence will be dropped in the model since with one or even two nutritional requirements (energy and protein) only two types of subsistence can be optimally combined. This simplistic case was defended above (see Nutritional Requirements). By finding this solution for the hunting and gathering cropping rates at different primary productivities, we are provided with an idea of how likely the adoption of agriculture/ pastoralism might have been. The larger the cropping rate $(\mathrm{min} / \mathrm{g})$ for agriculture/pastoralism can be and still be adopted, the more likely it is that this transition will occur.

Figure 9 presents the solutions to the general linear program foraging model for environments with different primary productivities. For each primary production value, the cropping rates for hunting and gathering 


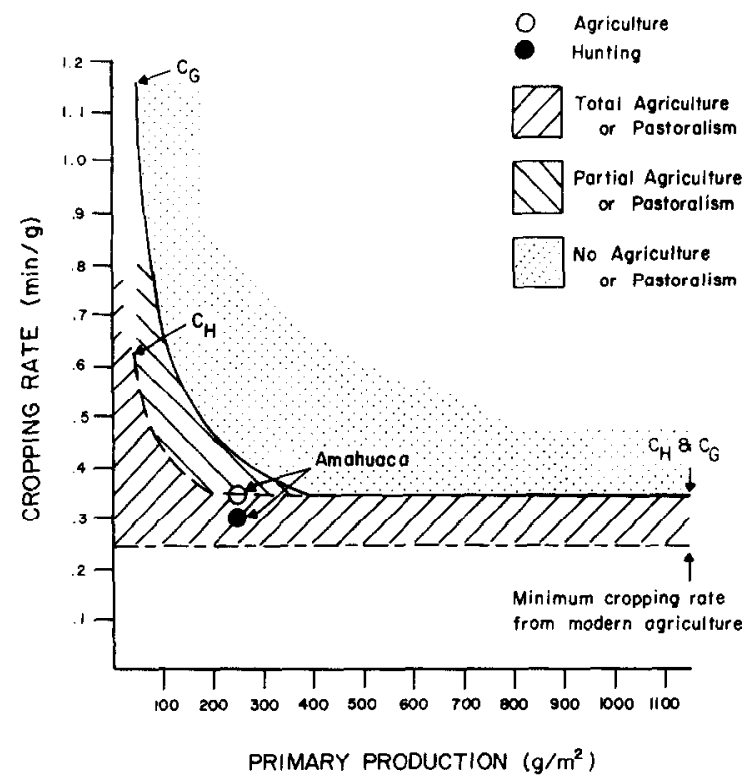

FIG. 9. The solution to the energy-maximizing linear program diet model at different terrestrial primary productivities illustrating what the cropping rates for hunting $\left(C_{H}\right)$ and gathering $\left(C_{G}\right)$ would have to be to lead either to agriculture or pastoralism: the domestication of plants or animals. The lower dashed line represents the lowest cropping rate for modern agriculture (Lawton 1973). Also plotted are the observed cropping rates for agriculture and hunting for the Amahuaca, a people subsisting on both agriculture and hunting, indicating that this is an optimal strategy given the available hunting cropping rate.

are predicted from the functional response regressions presented above. With these hunting and gathering cropping rates acting as constants, the ceiling value of the cropping rate for agriculture/pastoralism that allows it to be adopted can be computed. This solution examines the initial conditions for adopting agriculture; with the adoption of agriculture and sedentism the environment's natural productivity may be changed, further reinforcing this process, but this cannot be addressed with the model.

If the cropping rate $(\mathrm{min} / \mathrm{g})$ for agriculture or pastoralism falls in the shaded region of Fig. 9, then farming or herding are energetically inefficient. The area (Fig. 9) with hash marks falling to the right encompasses cropping rates for farming or herding which lead to partial replacement of gathering by herding or farming. Finally, the area (Fig. 9) with hash marks falling to the left encompasses farming or herding cropping rates that would lead to the abandonment of both hunting and gathering. Examination of Fig. 9 indicates that hunting generally will be maintained the longest as a foraging mode as agriculture or pastoralism are adopted.

The predictions of this extension of the model can be tested using data 
on primitive horticulturalists. Using Carneiro's data (1968) on the Amahuaca, their cropping rates for hunting and agriculture were estimated. The hunting cropping rate was calculated using Lee's (1979) San values for tool making and meal preparation. Using the cropping rates in the foraging model, these Amazonian hunter-farmers are predicted to hunt as well as farm, which is what they are observed to do. The energy-maximizing diet can also be found $(256 \mathrm{~g}$ meat/day and $930 \mathrm{~g}$ of farm produce/ day); this predicted diet, $22 \%$ meat, is close to the observed diet (meat approximately $20 \%$ ).

Why do people become dependent on domestic plants or animals? A number of researchers have provided explanations for this question (e.g., Binford 1980; Brown 1985, 1986; Varich 1982; Hitchcock 1982; Cohen 1977; Christenson 1980; Reidhead 1980; Green 1980; Earle 1980). First, agriculture/pastoralism, when adopted under the criteria of the linear program model, provides a diet with more energy and protein. Hitchcock (1982) argues that Basawara have poorer nutrition with agriculture and sedentism, but this may be due to environmental degradation. This may also be the case for the Rofaifo in New Guinea (Dwyer 1983).

Second, agriculture/pastoralism may provide a more reliable food source, with less variability between years than if hunter-gatherers relied solely upon the available food in the environment. Hitchcock (1982) found that Basawara that had become sedentary and relied on agriculture/pastoralism had more uniform food availability than their relatives that remained hunter-gatherers. To address this question the risk sensitive model presented above might be more appropriate, if the data were available to solve it.

Third, examination of Fig. 9 suggests that agriculture or pastoralism should be most rapidly incorporated into foraging in environments with low productivity. This agrees with Cohen's (1977), Binford's (1980), and Brown's $(1985,1986)$ ideas that agriculture emerged as a response to food shortages (low productive environments). Whether this low productivity is created by human overpopulation as suggested by Cohen (1977) or a major environmental change concomitant with the late-Pleistocene extinction of megafauna (Hester 1967; Guilday 1967) cannot be discerned from the model. Nonetheless, either case could make the conditions for the adoption of agriculture/pastoralism more likely.

The model's usefulness in addressing the adoption of agriculture/pastoralism is as a heuristic tool. It gives us a means possibly to unravel past human events in a quantitative fashion and determine how important other factors such as sedentism might have been, since the predictions of the model were made without considering sedentism. The same procedure could be used to address Paleolithic adaptations if we could determine the effects of different technologies on cropping rates and past envi- 
ronmental productivities from paleontological estimates. If this could be done, we could possibly overcome some of the problems of interpreting archaeological sites and artifacts (Freeman 1981; Binford 1985).

\section{What If the Model Captures the Essential Characteristics of Hunter-Gatherer Foraging?}

Given the quality and quantity of data used in constructing the model, the results must be questioned. Nonetheless, the comparison of predicted and observed diets is remarkably good and consistently in accord with a foraging strategy of energy or protein maximization. This indicates a potential utility in the approach. Furthermore, if energy or protein limitation is operating on hunter-gatherers, then their foraging decisions might be limiting fitness. The demonstration that foraging is important to human individual fitness is not well documented (see Introduction) and is very difficult to study. However, we can determine whether important aspects of human fitness can be predicted on the basis of foraging considerations.

Because the body size of hunter-gatherers often is small compared to other people, and different hunter-gatherers vary in their statures (Lee 1979; Hill et al., 1984; Hawkes et al., 1982), it may be that stature is selected for as a response to the foraging environment. To examine the effect of body size on hunter-gatherer foraging efficiency, the constraint equations for individual !Kung with and without dependents can be made weight dependent (Table 6). Stomach capacity is assumed to be proportional to weight, while metabolism is proportional to weight raised to the 0.75 power plus the metabolism of dependents (Peters 1983). No data are available to make cropping rates weight dependent. Therefore, the cropping time constraint equation is assumed to be unchanged. Finally, no

TABLE 6

BODY WEIGHT (kg) DEPENDENT FoRAGING CONSTRAINTS FOR SAN FOR INDIVIDUALS WITH AND WITHOUT DEPENDENTS

\begin{tabular}{lll}
\hline & \multicolumn{1}{c}{ Without dependents } & \multicolumn{1}{c}{ With dependents } \\
\hline Stomach (g) & $15.61 W$ & $15.61 W+179.6 \geqslant M+0.67 V$ \\
Time (min) & $0.34 M+0.42 V$ & $0.34 M+0.35 V \geqslant 393$ \\
Metabolism (kcal/day) & $E+728$ & $E \geqslant 3 M+3.05 V$ \\
& $E=$ not growing: 114 W.75 \\
& not growing and lactating: $114 W^{.75}+400$ \\
& growing: 136 W.75 \\
& growing and lactating: 136 $W^{.75}+400$ \\
& (Wohl and Goodhart 1968) \\
\hline
\end{tabular}


data on sexual differences are available to modify the foraging constraints.

Solving the weight dependent constraints (Fig. 10), a !Kung individual maximizing energy/protein intake is able to satisfy his/her energy requirements when a weight of $12.6 \mathrm{~kg}$ is reached. Lee (1979) found that the weaning of young occurs at approximately 3 years of age (average weight $=12+\mathrm{kg}$ ). This suggests that weaning may be a response to the juvenile's ability to forage for itself; but for some reason the juveniles do not forage but remain dependent until 15-18 years of age (approximately 27 $\mathrm{kg}$ ). This dependence could arise from a number of factors including dangers in the environment such as predators (e.g., lions), thermal imbalance, water loss, and the necessity of learning how to forage. Nonetheless, this prolonged dependence would be easy to terminate (i.e., forced foraging) in times of nutritional stress, in comparison to nursing.

A !Kung female has sufficient energy intake to satisfy her own energy requirements and those of lactation (approx. $2250 \mathrm{kcal} /$ day) at $21 \mathrm{~kg}$, if her growth terminates. If her growth continues, lactation is not energetically affordable for a !Kung female (approx $2900 \mathrm{kcal} /$ day) until a weight of $30 \mathrm{~kg}$ is attained. The solution for a !Kung female without dependents is used in this example, because she will not have dependents aiding in the preparation of gathered foods or additional individuals to forage for until several years after the family has been started. Finally, a !Kung

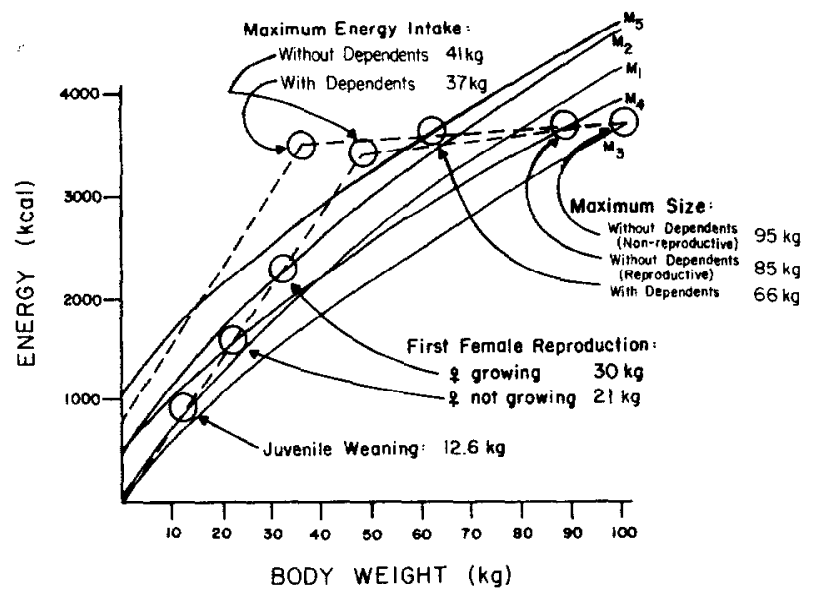

FIG. 10. The linear program energy-maximizing diet model is solved for San of different sizes. The energy intake for a San without dependents $\left(I_{\mathrm{L}}\right)$ and a San with dependents $\left(I_{\mathrm{D}}\right)$ are presented as dashed lines. The energy requirements for San are presented as solid lines: $\mathbf{M}_{1}$-growing individual, $\mathbf{M}_{2}$ - growing individual female that is lactating, $\mathbf{M}_{3}$-nongrowing individual, $M_{4}$-nongrowing female that is lactating, $M_{5}$ - nongrowing individual with dependents. Various life history stages are denoted in the graph. 
individual can support the average number of dependents observed in the population without requiring their help in foraging at a weight of approximately $37 \mathrm{~kg}$.

Lee (1979) found that females do not bear young until 18-22 years of age, an approximate weight of $35 \mathrm{~kg}$. This indicates that !Kung women postpone reproduction until they reach weights greater than needed to satisfy their lactation energy or protein demands and feed weaned children without help. Therefore, whether this postponement of reproduction (age at first reproduction) is maintained culturally and/or nutritionally by other factors (Bentley 1985) cannot be assessed using the model.

!Kung are computed to have a maximum net energy intake at $41 \mathrm{~kg}$, whether growing or not. At this weight, the individual can supply the greatest net energy for him or herself. At $37 \mathrm{~kg}$, however, an individual can provide the most energy for him or herself and dependents. Nonetheless, Lee (1979) found that !Kung adults average $45 \mathrm{~kg}$, indicating that an individual achieves a body mass that tends to maximize his/her personal energy intake. Also, !Kung are predicted not to weigh more than $66 \mathrm{~kg}$, with dependents, and $95 \mathrm{~kg}$, without dependents. Weights for the largest !Kung are not available for comparison.

The above results indicate that !Kung body sizes at weaning and for an average adult appear to correlate better with an individual's foraging efficiency than with a strategy which includes dependents, i.e., the group. This is opposite the finding for diet choice presented above and for the size at first reproduction. The dichotomy between body size selection being based on individual needs and diet choice including dependents' needs is not a contradiction. The potential to maximize personal energy/ protein intake through body size selection is necessary to provide individuals with the greatest potential for survival in periods of food scarcity. But in times of sufficient food, diet can be behaviorally modified to provide for the additional needs of dependents. This provides a flexibility for adult !Kung based upon behavior, while maintaining an inflexible morphological advantage. Therefore, in times of nutritional stress, individuals should forage for themselves which maximizes their personal survival; this does happen on occasion (Lee 1979).

Throughout the analysis, the number of !Kung dependents has been considered a constant. This value, however, is not a constant but should be maximized for the !Kung to have the greatest evolutionary fitness. By using the foraging model's constraints (Table 6) and making the parameters that include dependents (digestive capacity, preparation of gathered food, energy/protein requirements) vary with the number of dependents, the model can then be solved for the maximum possible number of dependents. The solution provides 0.81 dependents/adult. Lee (1979) reports 0.54 dependents for each adult; however, Howell's (1976) demographic 
data for the !Kung shows that they would have 0.73 dependents/adult if juvenile mortality were eliminated. Therefore, the !Kung appear to have a fecundity value that approaches the predicted maximum based on nutritional considerations.

\section{CONCLUSIONS}

A linear program model of hunter-gatherer diet choice is developed. It includes constraints for (1) daily feeding time of a form different from that commonly used in anthropological studies, but more appropriate to hunter-gatherers, (2) digestive capacity which limits the physiological processing of foods, and (3) nutritional requirements for the people. It is the trade-off among these different constraints that determines the optimal diet for different goals (energy/protein maximization, time minimization, risk aversion, etc.).

Comparing the model's solutions to observed hunter-gatherer diet choices indicates that a strategy of energy/protein maximization may bc employed. This foraging strategy has important implications for family size, body size, how diets will change in different environments, the sexual division of labor, the adoption of agriculture/pastoralism, and the types of environments in which hominids may have evolved, since hunting-gathering is the earliest livelihood. By no means is this model complete or necessarily correct, since the paucity of data makes its construction and findings very fragile. Nonetheless, the apparent success of the model, using available data on hunter-gatherers, makes further investigations warranted.

If the model and its predictions are correct, we must envision that man, as a hunter-gatherer, evolved in an environment where food was in short supply. Why else would man adopt a strategy of energy/protein maximization? Therefore, ecological methods of foraging theory may provide valuable insights into the evolution of human biology and culture. This claim has been made elsewhere (e.g., Smith 1979, 1983; Winterhalder and Smith, 1981; Hawkes et al., 1982; Hawkes and O'Connell 1985; Sih and Milton 1985; Smith 1983; Keene 1981, 1982), using a different type of model and/or approach.

\section{ACKNOWLEDGMENTS}

I thank T. W. Schoener, S. Lima, R. Lowe, R. Charnov, K. Hawkes, J. B. Slade, and two anonymous reviewers for comments. The motivation to write this paper was provided by discussions with other Harvard Junior Fellows. 


\section{REFERENCES CITED}

Arnold, Steven $J$.

1981 The microevolution of feeding behavior. In Foraging behavior: ecological, ethological, and psychological approaches, edited by A. C. Kamil and T. D. Sargent, pp. 409-453. Garland Press, New York.

Belovsky, Gary E.

1978 Diet optimization in a generalist herbivore: the moose. Theoretical Population Biology 14:105-134.

1981 Optimal activity times and habitat choice of moose. Oecologia (Berlin) 48: 22-30.

1984a Herbivore optimal foraging: a comparative test of three models. American Naturalist 124:97-115.

1984b Summer diet optimization by beaver. American Midland Naturalist 111:209222.

1984c Snowshoe hare optimal foraging and its implications for population dynamics. Theoretical Population Biology 25:235-264.

Bentley, Gillian R.

1985 Hunter-gatherer energetics and fertility: a reassessment of the !Kung San. Human Ecology 13:79-109.

Best, C. H.

1952 The Living Body. Holt, New York.

Best, C. H., and N. B. Taylor

1945 The physiological basis of medical practice. Williams \& Wilkins, Baltimore.

Binford, Lewis R.

1980 Willow smoke and dogs' tails: hunter-gatherer settlement systems and archaeological site formation. American Antiquity 45:4-20.

1985 Human ancestors: changing views of their behavior. Journal of Anthropological Archaeology 4:292-327.

Blackburn, R. H.

1982 In the land of milk and honey: Obiek adaptations to their forests and neighbors. In Politics and history in band societies, edited by Eleanor Leacock and Richard B. Lee, pp. 283-305. Cambridge Univ. Press, Cambridge.

Blurton Jones, Nicholas G., and R. M. Sibley

1978 Testing adaptiveness of culturally determined behavior: do Bushmen women maximize their reproductive success by spacing births widely and foraging seldom? In Human behaviour and adaptation, edited by Nicholas G. Blurton Jones and V. Reynolds, pp. 135-157. Society for the Study of Human Biology Symposium No. 18. Taylor \& Francis, London.

Borgerhoff Mulder, Monique, and Caro, T. M.

1985 The use of quantitative observational techniques in anthropology. Current Anthropology 26:323-335.

Bray, J. R., and L. A. Dudkiewicz

1963 The composition, biomass and productivity of two Populus forests. Bulletin of the Torrey Botanical Club 90:298-308.

Brown, Cecil $\mathrm{H}$.

1985 Mode of subsistence and folk biological taxonomy. Current Anthropology 26:43-64.

1986 The growth of ethnobiological nomenclature. Current Anthropology 27:1-19.

Brown, Judith $\mathrm{K}$.

1970 A note on the division of labor by sex. American Anthropologist 72:1073-1078. 
Campbell, Gaylon S.

1977 An introduction to environmental biophysics. Springer-Verlag, New York.

Caraco, Thomas

1980a On foraging time allocation in a stochastic environment. Ecology 61:119-128.

$1980 \mathrm{~b}$ An empirical demonstration of risk-sensitive foraging preferences. Animal Behavior 28:820-830.

1981 Energy budgets, risk and foraging preferences in dark-eyed juncos (Junco hyemalis). Behavioral Ecology and Sociobiology 8:213-217.

Carneiro, Robert L.

1968 The transition from hunting to horticulture in the Amazon Basin. Proceedings of the Eighth Congress of Anthropological and Ethnological Sciences, 224-248.

Cashdan, Elizabeth

$1984 \mathrm{G} /$ /ana territorial organization. Human Ecology 12:443-463.

Charnov, Eric $\mathbf{L}$.

1976 Optimal foraging: attack strategy of a mantid. American Naturalist 109:343352.

Christenson, Andrew L.

1980 Change in the human food niche in response to population growth. In Modeling change in prehistoric subsistence economies, edited by Timothy $\mathrm{K}$. Earle and Andrew L. Christenson, pp. 31-72. Academic Press, New York.

Cohen, M. N.

1977 The food crisis in prehistory: overpopulation and the origins of agriculture. Yale

Curr, Edward M. Univ. Press, New Haven.

1886-1887 The Australian race (4 vols.). Ferres, Melbourne.

Davidson, S., and R. Passmore

1969 Human nutrition and dietetics. Williams \& Wilkins, Baltimore.

Durham, William H.

1981 Overview: optimal foraging analysis in human ecology. In Hunter-gatherer foraging strategies: ethnographic and archeological analyses, edited by Bruce Winterhalder and Eric Alden Smith, pp. 218-231. Univ. of Chicago Press, Chicago.

Duvigneaud, P., and S. Denaeyer-DeSmet

1970 Biological cycling of minerals in temperate deciduous forests. Ecological Studies 1:199-225.

Dwyer, Peter D.

1982 Prey switching: a case study from New Guinea. Journal of Animal Ecology 51:529-542.

1983 Etolo hunting performance and energetics. Human Ecology 11:145-174.

1985 Choice and constraint in a Papua New Guinean food quest. Human Ecology 13:49-70.

Dwyer, Peter D., and Monica Minnegal

1985 Andaman islanders, pygmies, and an extension of Horn's model. Human Ecology 13:111-119.

Earle, Timothy $\mathrm{K}$.

1980 A model of subsistence change. In Modeling change in prehistoric subsistence economies, edited by Timothy K. Earle and Andrew L. Christenson, pp. 1-29. Academic Press, New York.

Earle, Timothy K., and Andrew L. Christenson (editors)

1980 Modeling change in prehistoric subsistence economies. Academic Press, New York. 
Ember, C. R.

1978 Myths about hunter-gatherers. Ethnology 17:439-448.

Eyre, Edward John

1845 Journals of expeditions of discovery into central Australia and overland from Adelaide to King George's Sound, in the years 1840-1841. T. and W. Boone, London.

Finch, Virginia A.

1972a Thermoregulation and heat balance of the East African eland and hartebeest. American Journal of Physiology 222:1374-1379.

$1972 \mathrm{~b}$ Energy exchanges with the environment of two East African antelopes, the eland and the hartebeest. Symposium of the Zoological Society of London 31:315-326.

Freeman, Leslie G.

1981 The fat of the land: notes on Paleolithic diet in Iberia. In Omnivorous primates: gathering and hunting in human evolution, edited by Robert S. O. Harding and Geza Teleki, pp. 104-165. Columbia Univ. Press, New York.

Garg, R. K., and L. N. Vyas

1975 Litter production in deciduous forest near Udaipur (South Rajasthan) India. In Tropical ecological systems: trends in terrestrial and aquatic research, edited

Garton, D. W. by Frank B. Golley and E. Medina, pp. 131-135. Springer-Verlag, New York.

1984 Relationship between multiple locus heterozygosity and physiological energetics of growth in the estuarine gastropod Thais haemastoma. Physiological Zoology 57:530-543.

Garton, D. W., R. K. Koehn, and T. M. Scott

1984 Multiple-locus heterozygosity and the physiological energetics of growth in the coot clam, Mulinia lateralis, from a natural population. Genetics 1089:445-455.

Gates, David M.

1980 Biophysical ecology. Springer-Verlag, New York.

Gould, Richard A.

1981 Comparative ecology of food-sharing in Australia and northwest California. In Omnivorous primates: gathering and hunting in human evolution, edited by Robert S. O. Harding and Geza Teleki, pp. 422-454. Columbia Univ. Press, New York.

Green, S. W.

1980 Broadening least-cost models for expanding agricultural systems. In Modeling change in prehistoric subsistence economies, edited by Timothy $\mathrm{K}$. Earle and Andrew L. Christenson, pp. 209-241. Academic Press, New York.

Grey, George

1841 Journals of two expeditions of discovery in North-western and Western Australia, during the years 1837, '38, and '39. T. and W. Boone, London.

Guilday, John E.

1967 Differential extinction during late-Pleistocene and Recent times. In Pleistocene extinctions: the search for a cause, edited by Paul S. Martin and H. E. Wright, Jr., pp. 121-140. Yale Univ. Press, New Haven.

Guyton, A. C.

1969 Textbook of medical physiology. Saunders, Philadelphia.

Hames, Raymond B.

1979 A comparison of the efficiencies of the shotgun and the bow in neotropical forest hunting. Human Ecology 7:21-52. 
Hames, Raymond B., and W. T. Vickers

1982 Optimal diet breadth theory as a model to explain variability in Amazonian hunting. American Ethnologist 9:358-378.

Harako, Reizo

1981 The cultural ecology of hunting behavior among Mbuti pygmies in the Ituri Forest, Zaire. In Omnivorous primates: gathering and hunting in human evolution, edited by Robert S. O. Harding and Geza Teleki, pp. 499-555. Columbia Univ. Press, New York.

Harris, Marvin

1977 Cannibals and kings. Random House, New York.

1979 Cultural materialism: the struggle for a science of culture. American Anthropologist 83:622-626.

Hassell, Mark P.

1978 The Dynamics of arthropod predator-prey systems. Princeton Univ. Press, Princton.

Hawkes, Kristen, Kim Hill, and James F. O'Connell

1982 Why hunters gather: optimal foraging and the Aché of eastern Paraguay. American Ethnologist 9:379-398.

Hawkes, Kristen, and James F. O'Connell

1981 Affluent hunters? Some comments in light of the Alyawara case. American Anthropologist 83:622-626.

1985 Optimal foraging models and the case of the !Kung. American Anthropologist 87:401-405.

Hawkes, Kristen, James F. O'Connell, Kim Hill, and Eric L. Charnov

1985 How much is enough? Hunters and limited needs. Ethology and Sociobiology 6:3-15.

Hayden, Brian

1981 Subsistence and ecological adaptations of modern hunter/gatherers. In Omnivorous primates: gathering and hunting in human evolution, edited by Robert S. O. Harding and Geza Teleki, pp. 344-421. Columbia Univ. Press, New York.

Hester, J. J.

1967 The agency of man in animal extinctions. In Pleistocene extinctions: the search for a cause, edited by Paul S. Martin and H. E. Wright, Jr., pp. 169-192. Yale Univ. Press, New Haven.

Hill, Kim, Kristen Hawkes, Ana Magdalena Hurtado, and Hillard Kaplan

1984 Seasonal variance in the diet of Aché hunter-gatherers in eastern Paraguay. Human Ecology 12:145-180.

Hill, Kim, Hillard Kaplan, Kristen Hawkes, and Ana Magdelena Hurtado

1985 Men's time allocation to subsistence work among the Ache of Eastern Paraguay. Human Ecology 13:29-47.

Hitchcock, R. K.

1982 Patterns of sedentism among the Basawara of eastern Botswana. In Politics and history in band societies, edited by Eleanor Leacock and Richard B. Lee, pp. 223-282. Cambridge Univ. Press, Cambridge.

Hixon, Mark A.

1982 Energy maximizers and time minimizers: theory and reality. American Naturalist 119:596-599.

Holling, C. S.

1965 The functional response of predators to prey density and its role in mimicry and population regulation. Memoirs of the Entomological Society of Canada 45:1-60. 
Howell, Nancy

1976 The population of the Dobe area !Kung. In Kalahari hunter-gatherers: studies of the !Kung San and their neighbors, edited by Richard B. Lee and Irven DeVore, pp. 137-151. Harvard Univ. Press, Cambridge.

Hurtado, Ana Magdalena, Kristen Hawkes, Kim Hill, and Hillard Kaplan

1985 Female subsistence strategies among Aché hunter-gatherers of eastern Paraguay. Human Ecology 13:1-28.

Kaplan, Hillard, and Kim Hill

1985a Hunting ability and reproductive success among male Aché foragers: preliminary results. Current Anthropology 26:131-133.

1985b Food sharing among Aché foragers: tests of explanatory hypotheses. Current Anthropology 26:223-246.

1986 Reply (to Minnegal and Dwyer, 1986). Current Anthropology 27:48-50.

Kaplan, Hillard, Kim Hill, Kristen Hawkes, and Ana Hurtado

1984 Food sharing among Aché hunter-gatherers of eastern Paraguay. Current Anthropology 25:113-115.

Keene, Arthur S.

1981 Optimal foraging in a nonmarginal environment: a model of prehistoric subsistence strategies in Michigan. In Hunter-gatherer foraging strategies: ethnographic and archeological analyses, edited by Bruce Winterhalder and Eric Alden Smith, pp. 171-193. Univ. of Chicago Press, Chicago.

1982 Prehistoric foraging in a temperate forest: a linear programming model. Academic Press, New York.

Klinge, H., W. A. Rodrigues, E. Brunig, and E. J. Fittkau.

1975 Biomass and structure in a central Amazonian rain forest. In Tropical ecological systems: trends in terrestrial and aquatic research, edited by Frank B. Golley and E. Medina, pp. 115-122. Springer-Verlag, New York.

Krebs, John R., J. T. Erichsen, and M. T. Webber

1977 Optimal prey selection in the great tit (Parus major). Animal Behavior 25: 30-38.

Krebs, John R., David W. Stephens, and W. J. Sutherland

1983 Perspectives in optimal foraging. In Perspectives in ornithology, edited by A. H. Brush and G. A. Clark, Jr., pp. 165-216. Cambridge Univ. Press, Cambridge.

Lawton, John H.

1973 The energy cost of "food-gathering'". In Resources and population, edited by B. Benjamin, P. R. Cox, and J. Peel, pp. 59-76. Academic Press, New York.

Leacock, Eleanor, and Richard B. Lee

1982 Introduction. In Politics and history in band societies, edited by Eleanor Leacock and Richard B. Lee, pp. 1-20. Cambridge Univ. Press, Cambridge.

Lee, D. H. K.

1964 Terrestrial animals in dry heat: man in the desert. In Handbook of physiology, Sec. 4, Adaptation to the Environment, edited by D. B. Dill, p. 551-582. American Physiological Society, Washington, DC

Lee, Richard B.

1968 What hunters do for a living, or, how to make out on scarce resources. In Man the hunter, edited by Richard B. Lee and Irven DeVore, pp. 30-48. Aldine, New York.

1979 The !Kung San: men, women and work in a foraging society. Cambridge Univ. Press, Cambridge.

1982 Politics, sexual and non-sexual, in an egalitarian society. In Politics and history in band societies, edited by Eleanor Leacock and Richard B. Lee, pp. 37-59. Cambridge Univ. Press, Cambridge. 
Lee, Richard B., and Irven DeVore (editors)

1968 Man the hunter. Aldine, New York.

1976 Kalahari hunter-gatherers: studies of the IKung San and their neighbors. Harvard Univ. Press, Cambridge.

Leith, $\mathrm{H}$.

1975 Modeling the primary productivity of the world. In Primary productivity of the biosphere. Ecological Studies 14, edited by H. Leith and Robert H. Whittaker, pp. 237-263. Springer-Verlag, New York.

Leslie, Paul W., James R. Bindon, and Paul T. Baker

1984 Caloric requirements of human populations: a model. Human Ecology 12:137162.

Malaisse, F., R. Freson, G. Goffinet, and M. Malaisse-Moussett

1975 Litter fall and litter breakdown in Miombo. In Tropical ecological systems: trends in terrestrial and aquatic research, edited by Frank B. Golley and E. Medina, pp. 137-152. Springer-Verlag, New York.

Mann, Alan E.

1981 Diet and human evolution. In Omnivorous primates: gathering and hunting in human evolution, edited by Robert S. O. Harding and Geza Teleki, pp. 10-36. Columbia Univ. Press, New York.

Marks, S. A.

1976 Large mammals and brave people: subsistence hunters in Zambia. Univ. of Washington Press, Seattle.

Martin, John F.

1983 Optimal foraging theory: a review of some models and their applications. American Anthropologist 85:612-628.

McCarthy, Frederick D., and Margaret McArthur

1960 The food quest and the time factor in aboriginal economic life. In Records of the American-Australian scientific expedition to Arnhem Land, Vol. 2, Anthropology and Nutrition, edited by C. P. Mountford, pp. 145-194. Melbourne Univ. Press, Melbourne.

McNair, J. N.

1979 A generalized model of optimal diets. Theoretical Population Biology 15:159170 .

Minge-Klevana, Wanda

1980 Does labor time decrease with industrialization? A survey of time-allocation studies. Current Anthropology 21:279-298.

Minnegal, Monica, and Peter D. Dwyer

1986 On hunting ability, reproductive success, and statistics. Current Anthropology 27:47-48.

Montieth, John L.

1973 Principles of environmental physics. American Elsevier, New York.

Oaten, Alan

1977 Optimal foraging in patches: a case for stochasticity. Theoretical Population Biology 12:263-285.

O'Connell, James F., and Kristen Hawkes

1981 Alyawara plant use and optimal foraging theory. In Hunter-gatherer foraging strategies: ethnographic and archeological analyses, edited by Bruce Winterhalder and F. A. Smith, pp. 99-125. Univ. of Chicago Press, Chicago.

Odum, Howard T.

1970 Summary, an emerging view of the ecological system at El Verde. In A tropical rainforest, edited by Howard T. Odum and R. F. Pigeon, pp. 1-191 to 1-281. United States Atomic Energy Commission, Division of Technical Information, Oak Ridge, TN. 
Ovington, J. D.

1962 Quantitative ecology and the woodland ecosystem concepts. In Advances in ecological research, edited by J. C. Cragg, pp. 103-192. Academic Press, New York.

Peters, Robert $\mathrm{H}$.

1983 The ecological implications of body size. Cambridge Univ. Press, Cambridge.

Porter, Warren P., and David Gates

1969 Thermodynamic equilibria of animals with environment. Ecological Monograph 39:227-244.

Pulliam, H. Ronald

1974 On the theory of optimal diets. American Naturalist 108:59-74.

1975 Diet optimization with nutrient constraints. American Naturalist 109:765-768.

Pyke, Graham H.

1984 Optimal foraging theory: a critical review. Annual Review of Ecology and Systematics 15:523-575.

Pyke, Graham H., and H. Ronald Pulliam, and Eric L. Charnov

1977 Optimal foraging: a selective review of theory and tests. Quarterly Review of Biology 55:137-54.

Reidhead, Van A.

1980 The economics of subsistence change: test of an optimization model. In Modeling change in prehistoric subsistence economies, edited by Timothy $\mathbf{K}$. Earle and Andrew L. Christenson, pp. $141-186$. Academic Press, New York.

Sahlins, Marshall D.

1968 Notes on the original affluent society. In Man the hunter, edited by Richard B. Lee and Irven DeVore, pp. 86-89. Aldine, New York.

1972 Stone Age economics. Aldine, Chicago.

1976 Culture and practical reason. Univ. of Chicago Press, Chicago.

Schoener, Thomas W.

1971 Theory of feeding strategies. Annual Review of Ecology and Systematics 2:369-403.

Sih, Andrew, and Katharine A. Milton.

1985 Optimal diet theory: should the !Kung eat mongongos? American Anthropologist 87:395-401.

Silberbauer, George

1981a Hunter/gatherers of the Central Kalahari. In Omnivorous primates: gathering and hunting in human evolution, edited by Robert S. O. Harding and Geza Teleki, pp. 455-498. Columbia Univ. Press, New York.

1981b Hunter and habitat in the Central Kalahari Desert. Cambridge Univ. Press, Cambridge.

1982 Political process in G/wi bands. In Politics and history in band societies, edited by Eleanor Leacock and Richard B. Lee, pp. 21-35. Cambridge Univ. Press, Cambridge, England.

Smith, Eric Alden

1979 Human adaptation and energetic efficiency. Human Ecology 7:53-74.

1983 Anthropological applications of optimal foraging theory: a critical review. Current Anthropology 24:625-651.

1985 Inuit foraging groups: some simple models incorporating conflicts of interest, Speth, John D. relatedness, and central-place foraging. Ethology and Sociobiology 6:27-47.

1983 Bison kills and bone counts: decision-making by ancient hunters. Univ. of Chicago Press, Chicago. 
Speth, John D., and Katherine A. Spielmann

1983 Energy source, protein metabolism and hunter-gatherer subsistence strategies. Journal of Anthropological Archaeology 2:1-31.

Stephens, David W., and John R. Krebs

1986 Foraging theory. Monographs in Behavioral Ecology. Princeton Univ. Press, Princeton, New Jersey.

Taghon, Gary L.

1981 Beyond selection: optimal ingestion rate as a function of food value. American Naturalist 118:202-214.

Tanaka, Jiro

1976 Subsistence ecology of Central Kalahari San. In Kalahari hunter-gatherers, edited by Richard B. Lee and Irven DeVore, pp. 98-119. Harvard Univ. Press, Cambridge.

Varich, H. I. D.

1982 Adaptive flexibility in a multiethnic setting: the Basawara of the southern Kalahari. In Politics and history in band societies, edited by Eleanor Leacock and

Webster, David Richard B. Lee, pp. 213-222. Cambridge Univ. Press, Cambridge.

1981 Late Pleistocene extinction and human predation: a critical overview. In Omnivorous primates: gathering and hunting in human evolution, edited by Robert S. O. Harding and Geza Teleki, pp. 556-594. Columbia Univ. Press, New York. Webster, David, and Gary Webster

1984 Optimal hunting and Pleistocene extinction. Human Ecology 12:275-289.

Werner, Earl E., and Donald J. Hall

1974 Optimal foraging and the size selection of prey by the bluegill sunfish (Lepomis macrochirus). Ecology 55:1042-1052.

Westoby, Mark

1974 An analysis of diet selection by large generalist herbivores. American Naturalist 108:290-304.

Whittaker, Robert

1970 Communities and ecosystems. MacMillan, New York.

Wiessner. P.

1982 Risk, reciprocity and social influences on !Kung San economics. In Politics and history in band societies, edited by Eleanor Leacock and Richard B. Lee, pp. 61-84. Cambridge Univ. Press, Cambridge.

Winterhalder, Bruce

1977 Foraging strategy adaptations of the boreal forest Cree: an evaluation of theory and models from evolutionary ecology. Ph.D. dissertation, Cornell Univ. Ithaca.

1980 Canadian fur bearer cycles and Cree-Ojibwa hunting and trapping practices. American Naturalist 115:870-879.

1981a Optimal foraging strategies and hunter-gatherer research in anthropology: theory and models. In Hunter-gatherer foraging strategies: ethnographic and archeological analyses, edited by Bruce Winterhalder and Eric Alden Smith, pp. 13-35. Univ. of Chicago Press, Chicago.

1981b Foraging strategies in the boreal forest: an analysis of Cree hunting and gathering. In Hunter-gatherer foraging strategies: ethnographic and archeological analyses, edited by Bruce Winterhalder and Eric Alden Smith, pp. 66-98. Univ. of Chicago Press, Chicago.

1983 Opportunity-cost foraging models for stationary and mobile predators. American Naturalist 122:73-84. 
Winterhalder, Bruce, and Eric Alden Smith (editors)

1981 Hunter-gatherer foraging strategies: ethnographic and archeological analyses. Univ. of Chicago Press, Chicago.

Wohl, M. G., and R. S. Goodhart

1968 Modern nutrition in health and disease. Lea \& Febiger, Philadelphia.

Woodburn, James C.

1968 An introduction to Hadza ecology. In Man the hunter, edited by Richard B. Lee and Irven DeVore, pp. 49-55. Aldine, New York.

Wyndham, C. $\mathrm{H}$.

1956 Heat regulations of Ma Sarwa (Bushmen). Nature (London), 178:869-870.

Wyndham, C. H., N. B. Strydom, J. S. Ward, J. F. Morrison, C. G. Williams, G. A. G. Bredell, M. J. E. Von Rahden, L. D. Holdsworth, C. H. Van Graan, A. J. Van Rensburg, and $A$. Munro.

1964 Physiological reactions to heat of Bushmen and of unacclimatized and acclimatized Bantu. Journal of Applied Physiology 19:885-888.

Yesner, David R.

1981 Archeological applications of optimal foraging theory: harvest strategies of Aleut hunter-gatherers. In Hunter-gatherer foraging strategies: ethnographic and archeological analyses, edited by Bruce Winterhalder and Eric Alden Smith, pp. 148-170. Univ. Chicago Press, Chicago. 